\title{
Targeted degradation of aberrant tau in frontotemporal dementia patient-derived neuronal cell models
}

M Catarina Silva ${ }^{1,2,3+}$, Fleur M Ferguson ${ }^{4,5+}$, Quan Cai, ${ }^{4,5}$, Katherine A Donovan ${ }^{4,5}$, Ghata Nandi ${ }^{1,2,3}$, Debasis Patnaik ${ }^{1,2,3}$, Tinghu Zhang ${ }^{4,5}$, Hai-Tsang Huang ${ }^{4,5}$, Diane E Lucente ${ }^{6,7,8,9}$, Bradford C Dickerson ${ }^{7,8,9}$, Timothy J Mitchison ${ }^{10,11}$, Eric S Fischer ${ }^{4,5}$, Nathanael S Gray ${ }^{4 *}$, Stephen J Haggarty 1,2,3*

${ }^{1}$ Chemical Neurobiology Laboratory, Center for Genomic Medicine, Massachusetts General Hospital, Harvard Medical School, Boston, United States; ${ }^{2}$ Department of Neurology, Massachusetts General Hospital, Harvard Medical School, Boston, United States; ${ }^{3}$ Department of Psychiatry, Massachusetts General Hospital, Harvard Medical School, Boston, United States; ${ }^{4}$ Department of Cancer Biology, DanaFarber Cancer Institute, Boston, United States; ${ }^{5}$ Department of Biological Chemistry and Molecular Pharmacology, Harvard Medical School, Boston, United States; ${ }^{6}$ Molecular Neurogenetics Unit, Center for Genomic Medicine, Massachusetts General Hospital, Harvard Medical School, Boston, United States; ${ }^{7}$ MGH Frontotemporal Disorders Unit, Department of Neurology, Massachusetts General Hospital, Harvard Medical School, Charlestown, United States; ${ }^{8}$ Gerontology Research Unit, Department of Neurology, Massachusetts General Hospital, Harvard Medical School, Charlestown, United States; ${ }^{9}$ Alzheimer's Disease Research Center, Department of Neurology, Massachusetts General Hospital, Harvard Medical School, Charlestown, United States; ${ }^{10}$ Department of Systems Biology, Harvard Medical School, Boston, United States; ${ }^{11}$ Laboratory of Systems Pharmacology, Harvard Medical School, Boston, United States

\begin{abstract}
Tauopathies are neurodegenerative diseases characterized by aberrant forms of tau protein accumulation leading to neuronal death in focal brain areas. Positron emission tomography (PET) tracers that bind to pathological tau are used in diagnosis, but there are no current therapies to eliminate these tau species. We employed targeted protein degradation technology to convert a tau PET-probe into a functional degrader of pathogenic tau. The hetero-bifunctional molecule QC01-175 was designed to engage both tau and Cereblon (CRBN), a substrate-receptor for the E3ubiquitin ligase CRL4 ${ }^{\text {CRBN }}$, to trigger tau ubiquitination and proteasomal degradation. QC-01-175 effected clearance of tau in frontotemporal dementia (FTD) patient-derived neuronal cell models, with minimal effect on tau from neurons of healthy controls, indicating specificity for diseaserelevant forms. QC-01-175 also rescued stress vulnerability in FTD neurons, phenocopying CRISPRmediated MAPT-knockout. This work demonstrates that aberrant tau in FTD patient-derived neurons is amenable to targeted degradation, representing an important advance for therapeutics. DOl: https://doi.org/10.7554/eLife.45457.001
\end{abstract}

\section{Introduction}

Tauopathies, such as frontotemporal dementia (FTD), progressive supranuclear palsy (PSP) and Alzheimer's disease (AD), are a group of neurodegenerative diseases characterized by the pathological 
accumulation of hyper-phosphorylated tau (P-tau) protein, in the form of intracellular paired helical filaments (PHFs) or neurofibrillary tangles (NFTs), within neurons and glia of affected brain regions, leading to cell death (Kosik et al., 1989; Morris et al., 2011; Cruts and Van Broeckhoven, 2015; Ghetti et al., 2015; Neumann et al., 2015; Olney et al., 2017; Goedert, 2004). Tauopathies can be either sporadic or inherited as autosomal dominant disease when caused by mutations in the MAPT gene encoding the microtubule-associated protein tau. FTD is the most common form of dementia in individuals under 60 years of age, affecting approximately 60,000 individuals in the USA alone, with an economic burden that is nearly twice that reported for AD (Galvin et al., 2017). Despite its devastating effects, there are currently no effective disease-modifying therapies, highlighting an urgent unmet need.

One of the major bottlenecks in developing effective therapies for tauopathies resides in the fact that molecular mechanisms leading to neuronal toxicity and death are still not entirely understood (Congdon and Sigurdsson, 2018; Panza et al., 2016; Medina, 2018; Götz et al., 2013). Cumulative evidence from murine tauopathy models and postmortem patient brain studies suggests that early tau post-translational modifications lead to misfolding, mislocalization, oligomerization, and changes in solubility. These events appear to be determinant toxicity effectors (Johnson and Stoothoff, 2004; Min et al., 2015; Wang et al., 2009; Götz et al., 2013; Kopeikina et alo, 2012; Tian et al., 2013; Yanamandra et al., 2013; Cowan and Mudher, 2013), whereas tau tangles alone are not sufficient to cause neuronal death (Cowan and Mudher, 2013; de Calignon et al., 2010; Kopeikina et al., 2012; Santacruz et al., 2005; Spires et al., 2006). Therefore, targeting early forms of toxic tau for clearance may facilitate the study of their role in disease etiology and be a promising therapeutic strategy to reduce neuronal degeneration.

A challenge in developing cell-permeable small molecules that target tau is the lack of a welldefined tau fold and active sites, in disease. Current investigative tau-directed therapeutics have focused on aggregation inhibitors (Brunden et al., 2010; Panza et alı, 2016; Bulic et al., 2009), activators of protein clearance through autophagy (Boland et alo, 2008; Krüger et alo, 2012; Medina, 2018; Wang and Mandelkow, 2012; Rubinsztein et al., 2015), and inhibition of tau kinases (Dolan and Johnson, 2010; Medina, 2018). Moreover, anti-tau immunotherapy has shown promise in animal models, but antibody affinity and specificity as well as strong immune responses pose critical challenges (Gu et al., 2013; Panza et al., 2016; Pedersen and Sigurdsson, 2015; Novak et al., 2017; Yanamandra et al., 2013). An alternative and promising strategy has focused on using anti-sense oligonucleotides (ASO) to decrease tau expression, leading to reversal of tau pathology in mouse and non-human primate models (DeVos et al., 2017; Mignon et alo, 2018; Xu et alo, 2014). Still, given potential limitations with existing approaches, developing small molecule agents that target early forms of toxic tau, and result in their degradation, may represent a uniquely advantageous strategy for halting tauopathies.

Targeted protein degradation approaches have expanded the landscape of druggable proteins by providing a mechanism to transform a non-functional protein binder into an effective targeted degrader (Gechijian et al., 2018). Targeted protein degraders, also known as PROTACs (PROteolysis TArgeting Chimeras), are an emerging strategy for ablating previously undruggable protein functions (Cromm et al., 2018; Gechijian et al., 2018; Xie et al., 2014; Lai and Crews, 2017). Structurally, degraders are hetero-bivalent compounds where a small molecule binder of the protein of interest is linked via a short linker to an E3-ligase recruiting molecule, such as the CRBN binder thalidomide (Figure 1A). This results in ternary complex formation between the protein of interest, the degrader molecule and the E3-ligase complex, in this case CUL4-RBX1-DDB1-CRBN (CRL4 ${ }^{\text {CRBN }}$ ), and induces ubiquitination and subsequent proteasomal degradation of the protein of interest (Figure 1B) (Fischer et al., 2014; Krönke et al., 2014; Lu et al., 2014; Chamberlain et al., 2014; Collins et al., 2017; Metzger et al., 2014).

In this study, we harnessed targeted protein degradation technology to transform one of the most clinically advanced tau PET (positron emission tomography) tracers, ${ }^{18} \mathrm{~F}-\mathrm{T} 807$ (or ${ }^{18} \mathrm{~F}-\mathrm{AV}$-1451), into the tau degrader QC-01-175 (Chien et al., 2013; Xia et al., 2013; Lowe et al., 2016). ${ }^{18} \mathrm{~F}-\mathrm{T} 807$ binds P-tau in vivo in a conformation-dependent manner, with highest efficiency in MAPT mutation carriers that produce AD-like PHF pathology (Jones et al., 2018), showing increased uptake in brain regions with significant tau deposition burden and little background binding in the cortex of normal brains. ${ }^{18} \mathrm{~F}-\mathrm{T} 807$ is the most advanced tau PET tracer in terms of its investigation in vivo, with studies completed in numerous tauopathies including AD and PSP (Holt et al., 2016; Jones et al., 2018; 


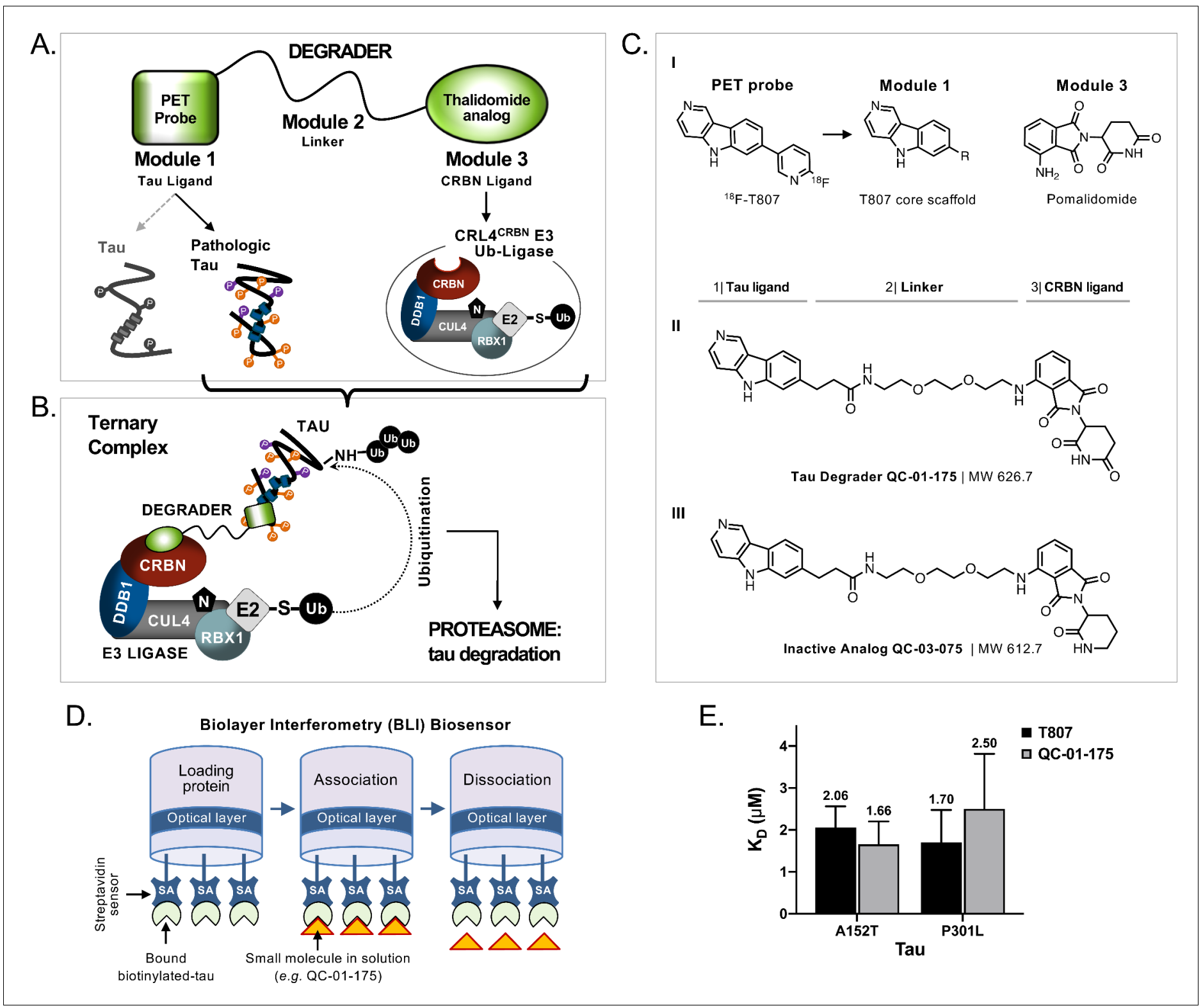

Figure 1. Design and working model for a new hetero-bifunctional tau degrader. (A) A degrader molecule was designed to preferentially recognize disease-associated forms of tau (Module 1), and simultaneously engage with CRBN in the CRL4 ${ }^{\text {CRBN }}$ E3 ubiquitin ligase complex (Module 3). (B) Degrader-mediated association of tau with CRL4 ${ }^{C R B N}$ and formation of a ternary complex is predicted to mediate tau ubiquitination and degradation by the proteasome. (C) QC-01-175 (I) was synthesized based on the T807 core scaffold for tau recognition, a thalidomide analog E3 ligand (pomalidomide) for CRBN engagement, and a linker designed for maximum target clearance efficiency (II). QC-03-075 is the inactive analog (III). (D) BLI Streptavidin (SA) biosensor assay to measure recombinant tau protein affinity to small molecules (e.g. T807, OC-01-175). (E) BLI results indicate that, in vitro, QC-01-175 binds to variant forms of tau within the same order of magnitude as T807. Bars represent mean $K_{D}(\mu M) \pm S D(n \geq 3)$. Figure $1-$ figure supplement 1 shows representative BLI sensograms and steady-state graphs for tau WT and each variant affinity to QC-01-175 and control compounds, with respective $K_{D}$ values. Figure 1-figure supplement 2 shows QC-01-175 effect on monoamine oxidase (MAO) activity. The following figure supplements are available for Figure 1.

DOl: https://doi.org/10.7554/eLife.45457.002

The following figure supplements are available for figure 1:

Figure supplement 1. In vitro characterization of tau-binding affinity to QC-01-175 and control compounds.

DOI: https://doi.org/10.7554/eLife.45457.003

Figure supplement 2. QC-01-175 effect on MAO activity.

DOI: https://doi.org/10.7554/eLife.45457.004 
Murugan et al., 2018; Saint-Aubert et alı, 2017; Schöll et al., 2016; Smith et al., 2016; Spina et al., 2017; Johnson et al., 2016; Schonhaut et al., 2017; Smith et al., 2018). We now demonstrate that a T807-derived degrader molecule, QC-01-175, preferentially degrades tau species in FTD patient-derived neuronal cell models, while sparing tau in healthy controls. Our results suggest that this degrader strategy may offer a promising opportunity for neutralizing the neurotoxic effects of tau.

\section{Results}

\section{Design and in vitro testing of targeted tau degraders}

We designed and synthesized a small library of 25 hetero-bifunctional molecules and candidate tau degraders, containing variants of the tau PET tracer T807 (module 1), coupled through a linker of variable size and attachment chemistry (module 2) to the E3-ligase recruiting ligand pomalidomide, which engages with CRL4 ${ }^{\text {CRBN }}$ (module 3, Figure $1 \mathrm{~A}$ and $\mathrm{C}-\mathrm{I}$ ). Through iterative design and testing in vitro and in ex vivo human neuronal cells, where each module element played a role in tau degradation efficacy, we identified the lead compound QC-01-175 (Figure 1C-II) (detailed structure-activity-relationship analysis to be published elsewhere). This compound contains the core $5 \mathrm{H}$-pyrido[4,3b]indole scaffold of T807, with the fluoro-pyridine ring replaced by a $[\mathrm{PEG}]_{2}$ linker attached to pomalidomide. We generated the corresponding negative control compound, QC-03-075, by replacing the glutarimide in pomalidomide with a $\delta$-lactam ring, thus abrogating $C R B N$-binding capacity (Figure 1C-III) (Huang et al., 2018).

A biolayer interferometry (BLI) assay was developed to measure in vitro affinity of the degrader molecule against wild-type (WT) and two variant forms of recombinant human tau: A152T and P301L (Figure 1D) (Kumaraswamy and Tobias, 2015; Petersen, 2017; Shah and Duncan, 2014). Known tau binders T807 and PE859 were used as positive controls to validate the BLI biosensor (Figure 1figure supplement 1A-B) (Okuda et al., 2017; Okuda et al., 2015). In this in vitro format, although weaker binding was observed compared to PE859 (Figure 1-figure supplement 1A), QC-01-175 was able to bind to immobilized, soluble forms of WT $\left(K_{D} 1.2 \mu \mathrm{M}\right), A 152 T\left(K_{D} 1.7 \mu M\right)$ and P301L $\left(\mathrm{K}_{\mathrm{D}} 2.5 \mu \mathrm{M}\right)$ within the same order of magnitude as the control T807 $\left(\mathrm{K}_{\mathrm{D}} 1.8 \mu \mathrm{M}, 2.1 \mu \mathrm{M}\right.$ and $1.7 \mu \mathrm{M}$, respectively) (Figure 1E, Figure 1-figure supplement 1A-B III, VI). As expected, in vitro QC-01175 and T807 displayed a significantly lower affinity for all recombinant immobilized tau forms than the reported $K_{D}$ of T807 for native, aggregated tau filaments from AD brain sections $\left(K_{D} 15 n M\right)$ (Chien et al., 2013; Gobbi et al., 2017; Xia et al., 2013). This property enables T807-based PET tracers to distinguish pathological tau species from the functional tau found in cells, and suggested that QC-01-175 may exhibit similar conformational selectivity. Comparison between binding of recombinant WT protein and variant tau forms, to either QC-01-175 or the controls PE859 and T807, indicates that T807 and derivatives have low affinity for monomeric, soluble protein, independent of the presence of a tau variant (Figure 1-figure supplement 1B).

The PET tracer ${ }^{18} \mathrm{~F}-\mathrm{T} 807$ has off-target activity against monoamine oxidase-B (MAO-B) and monoamine oxidase-A (MAO-A) (Lemoine et al., 2018; Vermeiren et al., 2018). MAO inhibition interferes with neurotransmitter signaling, complicating phenotypic analysis, and in the clinic is associated with undesired risks of hypertensive crisis and with drug-drug interactions. To test if modifications introduced to the T807 scaffold increase MAO off-target activity of the degrader, we tested T807 and QC-01-175 in an in vitro MAO assay, using parnate, a known MAO inhibitor as positive control, and pomalidomide as a negative control. QC-01-175 showed reduced inhibition of MAO relative to $\mathrm{T} 807$ ( $\mathrm{IC}_{50} 8.56 \mu \mathrm{M}$ vs $0.14 \mu \mathrm{M}$, respectively) (Figure 1-figure supplement 2). Together, in vitro testing of QC-01-175 suggests that it has a preserved tau ligand-binding capacity and reduced off-target MAO inhibition.

\section{QC-01-175 promotes tau clearance in a human neuronal cell model of tauopathy}

We employed two tauopathy cell models to assess the activity of QC-01-175 in human neurons, one derived from a PSP patient carrier of the tau-A152T risk variant, and one derived from a behavioralvariant FTD patient carrier of the tau-P301L autosomal dominant mutation (both heterozygous, Figure 2-source data 1) (Seo et al., 2017; Silva et al., 2016; Coppola et al., 2012; Mirra et al., 
1999). Post-mitotic neurons were generated from patients' induced pluripotent stem cells (iPSC)derived cortical-enriched neural progenitor cells (NPCs) subsequently differentiated into neurons for a period of 6 to 8 weeks, as previously described (Cheng et al., 2017; Silva et al., 2016; Seo et al., 2017). These patient-specific cellular models that express tau at endogenous levels, recapitulate disease-relevant tau phenotypes ex vivo (Fong et al., 2013; Silva et al., 2016) and present a valuable opportunity to test emerging therapeutics directly against a clinically relevant model of human disease (Dolmetsch and Geschwind, 2011; Silva et al., 2017; Wan et al., 2015; Inoue et al., 2014).

In A152T neurons treated with OC-01-175 for $24 \mathrm{hr}$ (Figure 2A), we observed a concentrationdependent reduction in total tau and P-tau levels by western blotting analysis (Figure 2B) and by tau ELISAs (Figure 2C). P-tau ${ }^{\mathrm{S} 96}$ and high-molecular-weight $\mathrm{P}$-tau ${ }^{\mathrm{S396}}$, identified as SDS-insoluble bands $>250 \mathrm{kDa}$ (Figure 2B), were effectively degraded at concentrations as low as $100 \mathrm{nM}$ QC-01175 , whereas maximal total tau clearance $\left(D_{\max }, 24 \mathrm{~h}\right)$ was achieved at $10 \mu \mathrm{M}$, consistent with expected binding preference of a T807-derivative for insoluble P-tau (Chien et alo, 2013; Lowe et al., 2016; Marquié et al., 2015; Xia et al., 2013). The observed $D_{\max }$, 24h of $75 \%$ for total tau and of $85 \%$ for P-tau 5396 , averaged across independent replicates (Figure 2-figure supplement 1), was well above the $50 \%$ mutant tau allele expressed by heterozygous neurons, indicating that both variant and WT forms of tau are recognized and degraded. Previous mass spectrometry (MS) FLEXITau analysis demonstrated that tau-A152T and tau-WT accumulate in similar proportions in these neurons (Silva et al., 2016), suggesting that QC-01-175 targets pathogenic tau conformations that include both WT and A152T tau, rather than tau variant exclusively. As the tau species present in iPSC-derived neurons vary in a differentiation- and maturation-dependent manner, we observed some variability in degradation effect across biological replicates (Figure 2-figure supplement $1 \mathrm{~A}-\mathrm{I})$. To ascertain this inherent variability, we plotted the levels of total tau and P-tau 5396 upon $24 \mathrm{hr}$ treatment with $1 \mu \mathrm{M}$ or $10 \mu \mathrm{M}$ doses of QC-01-175 across nine independent experiments. QC-01-175 promoted between 50 and $100 \%$ tau clearance, a statistically significant reduction relative to vehicle (Figure 2-figure supplement $1 \mathrm{~J}$ ). Conversely, the negative control QC-03075 (Figure 2D) showed no effect on the levels of total tau and P-tau ${ }^{\mathrm{S} 396}$ at all concentrations tested, indicating that engagement with CRL4 $4^{C R B N}$ is required for OC-01-175-mediated tau clearance (Figure 2E, $F$ and Figure 2-figure supplement 1J).

We employed immunofluorescence (IF) of tau in A152T neurons to assess the effect of treatment with $10 \mu \mathrm{M}$ OC-01-175 for $24 \mathrm{hr}$. Total tau (K9JA antibody), P-tau ${ }^{5396 / 5404}$ (PHF-1 antibody) and neuronal marker MAP2 were imaged, and a clear reduction in tau and P-tau ${ }^{\mathrm{S} 396 / 5404}$ were observed relative to vehicle- or QC-03-075-treated neurons (Figure 2G).

Next, we tested whether QC-01-175 could degrade multiple FTD-relevant tau species by repeating the ELISA tau quantification assay in tau-P301L neurons. OC-01-175 effected concentrationdependent degradation of total and $\mathrm{P}$-tau ${ }^{\mathrm{S} 396}$ at the $24 \mathrm{hr}$ time point, with a $D_{\max }, 24 \mathrm{~h}$ of $60 \%$ achieved at $1 \mu \mathrm{M}$ compound for both tau species (Figure 2-figure supplement 2A). QC-03-075 had minimal effect on tau levels (Figure 2-figure supplement 2B). These effects were corroborated by western blotting analysis, where $24 \mathrm{hr}$ treatment with $1 \mu \mathrm{M} \mathrm{OC}-01-175$ resulted in a 70\% reduction in total tau and an $80 \%$ reduction of $\mathrm{P}$-tau ${ }^{\mathrm{S} 396}$, comparable to the effect in $\mathrm{A} 152 \mathrm{~T}$ neurons, whereas QC-03-075 had no effect on the levels of either tau species (Figure 3-figure supplement $1 A, B)$. Collectively, these results demonstrate that $\mathrm{QC}-01-175$ targets multiple forms of tau for degradation in FTD neuronal cell models.

\section{QC-01-175 preferentially degrades tau species found in FTD neurons vs. healthy controls}

To investigate the ability of QC-01-175 to discriminate between normal and disease-associated tau, we tested our degrader against three independent, non-affected iPSC-derived neuronal cell models expressing WT tau, control neurons 1-3, in a tau ELISA assay (Figure 2-source data 1). These control neuronal cultures also contain reduced levels of the low-solubility $\mathrm{P}$-tau ${ }^{5396}$ species present in the FTD-patient-derived neurons (Figure 3-figure supplement 1C vs. A, B) (Silva et alo, 2016). No significant degradation of tau or P-tau ${ }^{\mathrm{S} 396}$ was observed after $24 \mathrm{hr}$ treatment with either QC-01175 or negative control $\mathrm{QC}-03-075$ at concentrations up to $1 \mu \mathrm{M}$ in all three control neurons (Figure 2H-J). We corroborated these results by western blotting, where $1 \mu \mathrm{M} \mathrm{OC}-01-175$ was unable to induce significant degradation of tau or P-tau after $24 \mathrm{hr}$ in control line 1 (Figure 3-figure supplement $1 \mathrm{C}$ ). At the highest dose of $10 \mu \mathrm{M}$, QC-01-175 induced $\sim 20 \%$ degradation of total 
A.

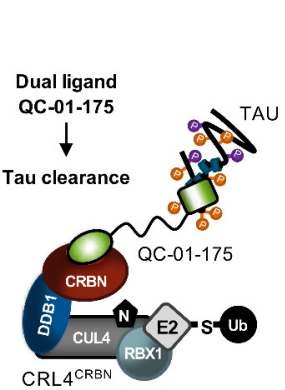

B.

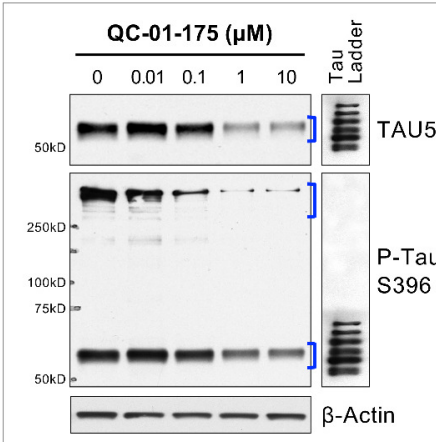

D.

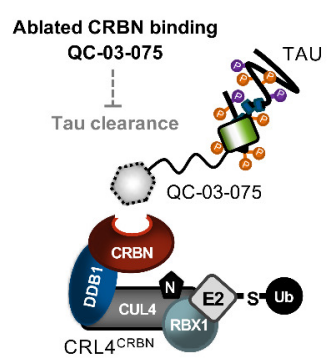

E.

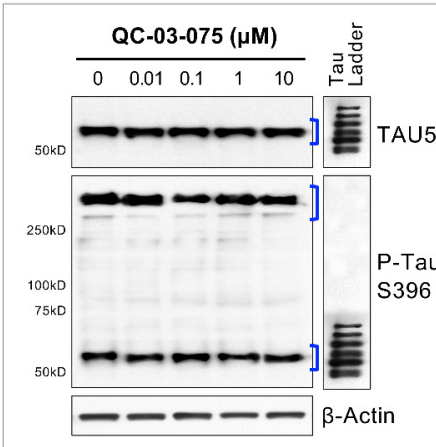

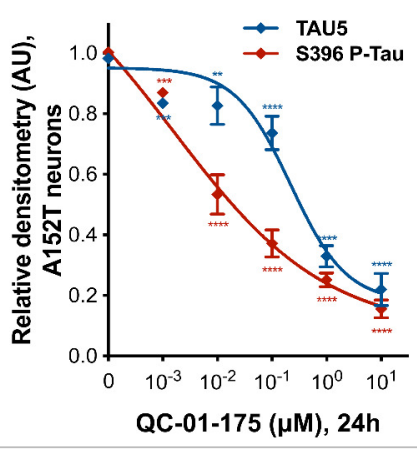

C.

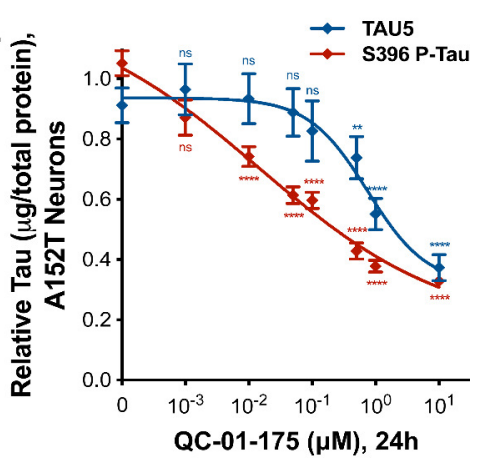

F.

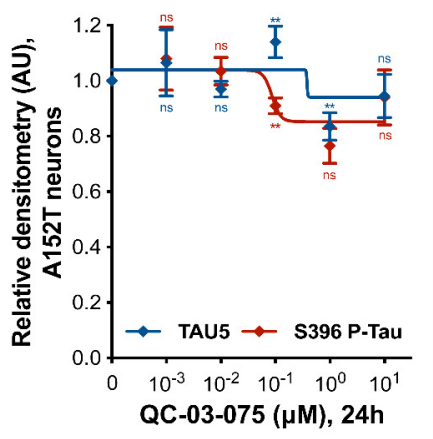

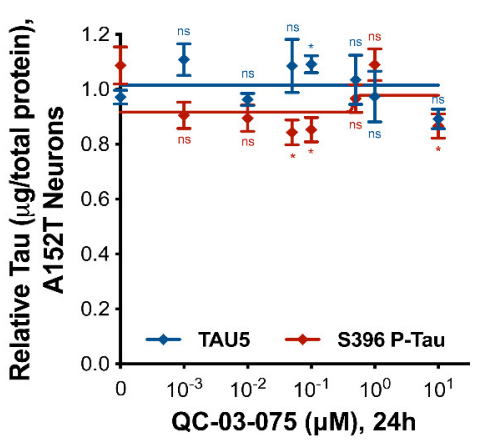

G.

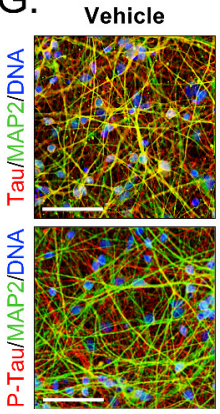

QC-01-175

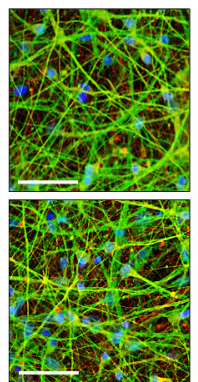

$\mathrm{H}$.

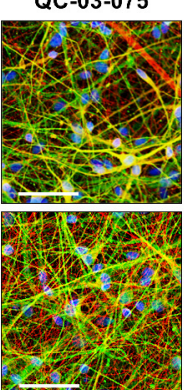

I.

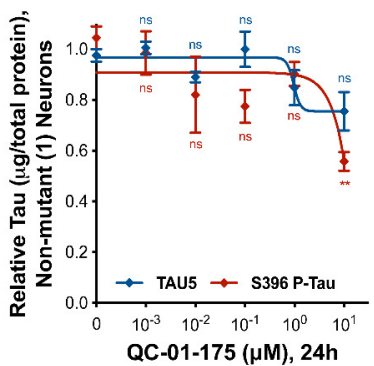

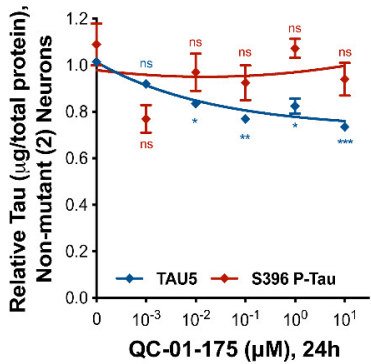

J.

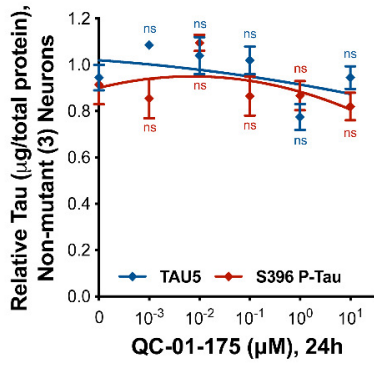

Figure 2. Concentration effect of QC-01-175 (A) on tau protein levels of A152T and control neurons. Analysis of total tau (TAU5) and phospho-tau (S396 P-tau) levels upon treatment by western blot (B) and ELISA (C). Analysis of total tau (TAU5) and phospho-tau (S396 P-tau) levels upon treatment with the negative control QC-03-075 (D), by western blot (E) and ELISA (F). Representative western blots are shown (B, E) with mean densitometry quantification (bands corresponding to brackets) $\pm \operatorname{SEM}(n=3)$. (C, F) For ELISA, data points represent mean tau levels $(\mu \mathrm{g}$ of total protein) normalized to vehicle-treated \pm SEM $(n=4)$. Both assays show QC-01-175 dose-dependent effect on tau levels, with QC-03-075 minimal effect ( 10\%). (G) IF of A152T neurons treated with vehicle or $10 \mu \mathrm{M}$ compound, immuno-probed for total tau (K9JA, red), P-tau (PHF-1, red) and the neuronal marker MAP2 (green), scale bar $50 \mu \mathrm{m}$. (H-J) Tau ELISA of control neurons treated with QC-01-175, which did not show a dose-dependent effect. (H) 8330-8-RC1 line; (I) MGH2069-RC1 line; (J) CTR2-L17-RC2 line. Data points represent mean tau levels ( $\mu \mathrm{g}$ of total protein) normalized to vehicle-treated $\pm \mathrm{SEM}$ $(n=3)$. All neurons were differentiated for 6 weeks and treated with compound for $24 \mathrm{hr}$. Student T-test between each concentration and vehicletreated tau levels ${ }^{n s} p>0.05,{ }^{*} p<0.05,{ }^{* *} p<0.01,{ }^{* \star *} p<0.001,{ }^{* \star * \star} p<0.0001$. Figure 2-figure supplement 1 depicts the variability of degrader effect across biological replicates, by western blot, with an overall 60\% to 90\% efficacy. Figure 2-figure supplement 2 shows degrader effect in P301L neurons and compares concentration effect across all lines. Figure 2-source data 1 summarizes the information pertaining to each cell line included in this study. Figure 2-source data 2 includes all ELISA data. The following figure supplements are available for Figure 2.

DOI: https://doi.org/10.7554/eLife.45457.005

The following source data and figure supplements are available for figure 2 :

Source data 1. Human neural cell lines derived from tauopathy-affected (progressive supranuclear palsy, PSP or behavioral variant of FTD, bvFTD) and age-matched unaffected individuals, and MAPT KO line employed in this study.

DOI: https://doi.org/10.7554/eLife.45457.008

Source data 2. Numerical description and statistics for data presented in Figure 2 and respective supplement 2 ELISAs.

Figure 2 continued on next page 
Figure 2 continued

DOI: https://doi.org/10.7554/eLife.45457.009

Figure supplement 1. Variability of the effect of QC-01-175 across biological replicates.

DOI: https://doi.org/10.7554/eLife.45457.006

Figure supplement 2. Demonstration of QC-01-175 effect in tau-P301L neurons.

DOI: https://doi.org/10.7554/eLife.45457.007

tau in two of the control lines (1 and 2) and had no effect in the third line. Similarly, $10 \mu \mathrm{M}$ QC-01175 degraded $\sim 40 \%$ of $\mathrm{P}$-tau ${ }^{\mathrm{S} 396}$ in control line 1 and had no significant effect in control lines 2 and 3. Comparative analysis of the effect of QC-01-175 across all cell lines tested suggests that QC-01175 is significantly more effective at inducing degradation of the forms of tau present in FTD patient-derived neurons (Figure 2-figure supplement 2C-E).

\section{Induced tau degradation is proteasome-dependent and occurs via CRL4 ${ }^{\text {CRBN }}$ binding}

To examine the mechanism of action of QC-01-175, we targeted each component predicted to be required for degrader-mediated tau clearance (Figure 3A-C, top panels). We treated A152T neurons with QC-01-175 at the minimum dose for maximum tau clearance, that is $1 \mu \mathrm{M}$ for $24 \mathrm{hr}(50$ $100 \%$ clearance), with or without pre-treatment for $6 \mathrm{hr}$ with specific inhibitors, followed by western blotting analysis of total tau and P-tau ${ }^{\mathrm{S} 396}$. First, excess lenalidomide or T807 that saturate ligand binding sites of CRBN or tau, respectively (Figure 3A), reversed QC-01-175-mediated tau degradation in a concentration-dependent manner (Figure 3A,D). Next, pre-treatment with MLN4924 (Pevonedistat), which inhibits NAE (neddylation activating enzyme NEDD8, and therefore neddylation ' $N$ ' of CUL4) (Lan et al., 2016) and consequently E3 ligase activity (Figure 3B), or pre-treatment with the irreversible proteasome inhibitor carfilzomib (Figure 3C) (Huang and Dixit, 2016), caused a concentration-dependent rescue of the effect of QC-01-175 (Figure 3B, C,E,F). In contrast, the autophagy inhibitor bafilomycin A1 (Baf.A1) did not reverse the degrader effect and further promoted tau clearance, possibly as a compensatory response between autophagy and proteasome clearance pathways (Figure 3B,E). The negative control QC-03-075 showed no significant effect on the levels of tau (Figure $3 A, B, D, E$ ). All inhibitors were utilized at concentrations that did not affect neuronal viability (data not shown). We also confirmed that QC-01-175 did not significantly affect the levels of CRBN by $24 \mathrm{hr}$, which remained constant across all concentrations (Figure 3-figure supplement 1D). Taken together, these data establish that QC-01-175-mediated tau degradation is dependent on CRBN and tau binding, neddylation (E3 ligase function) and proteasome function, but not autophagy, consistent with the proposed mechanism of action (Figure 1B).

As additional controls for specificity, we treated all neurons with the CRBN ligand lenalidomide or the tau ligand $\mathrm{T} 807$ at concentrations of $1 \mu \mathrm{M}$ and $10 \mu \mathrm{M}$ (Figure 2-figure supplement 1J, Figure 3-figure supplement $\left.1 \mathrm{~A}-\mathrm{C}_{1}\right)$. Across biological replicates, lenalidomide induced a significant up-regulation of $\mathrm{P}$-tau ${ }^{\mathrm{S} 396}(-30 \%$ and $90 \%$ at $1 \mu \mathrm{M}$ and $10 \mu \mathrm{M}$, respectively; Figure 2-figure supplement 1J) in A152T neurons, indicating that CRBN inhibition alone may lead to accumulation of P-tau in these neurons, which are more sensitive to modulators of the proteasome than healthy neurons (Silva et al., 2016). We also observed that T807 treatment alone could lead to a small upregulation of both total and P-tau (10-30\%) in A152T neurons (Figure 2-figure supplement 1J) Jones et al., 2018. Together, these results show that the action of the bifunctional degrader QC01-175 cannot be recapitulated by treatment with its independent components.

Next, we performed co-immunoprecipitation (co-IP) assays in degrader-treated A152T neurons, by pulling down either the CRL4 ${ }^{\mathrm{CRBN}}$ component DDB1 or tau, to test ternary complex predicted interactions (Figure 1B). We performed this experiment upon $4 \mathrm{hr}$ of $1 \mu \mathrm{M} \mathrm{QC}-01-175$ treatment, under the assumption that maximum engagement would be captured within a shorter interval. To ensure detection of the tau-degrader-CRL4 ${ }^{\text {CRBN }}$ binding complex before tau clearance occurred, we pre-treated samples with either carfilzomib or bortezomib proteasome inhibitors for $30 \mathrm{~min}$ (Huang and Dixit, 2016) to promote accumulation of the complex. Immunoprecipitation of DDB1 and follow-up western blotting analysis showed co-IP with both total tau (TAU5) and P-tau (PHF-1) upon QC-01-175 treatment \pm carfilzomib (Figure 4A). There was also a weak detection of total tau and P-tau in vehicle and negative control QC-03-075 treated samples, suggesting that some basal 
A.
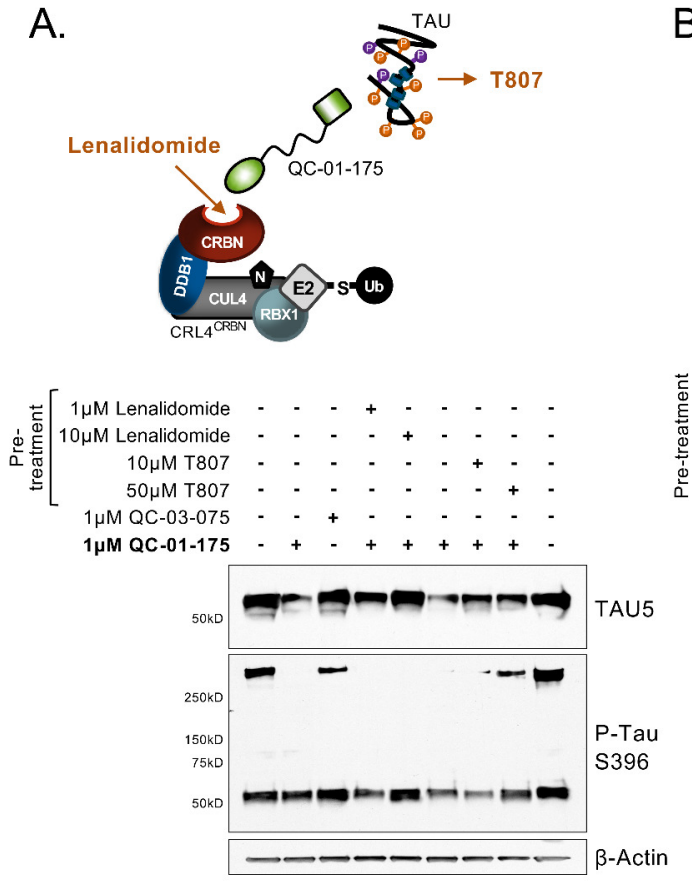

D.

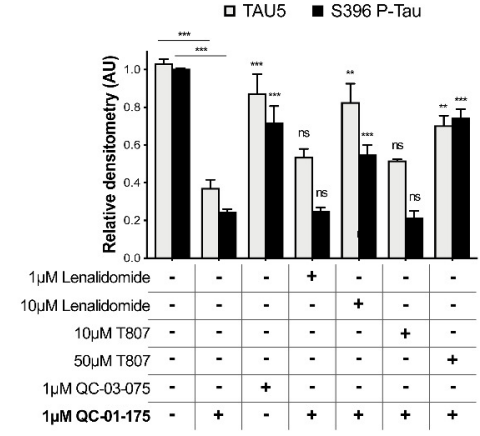

B.
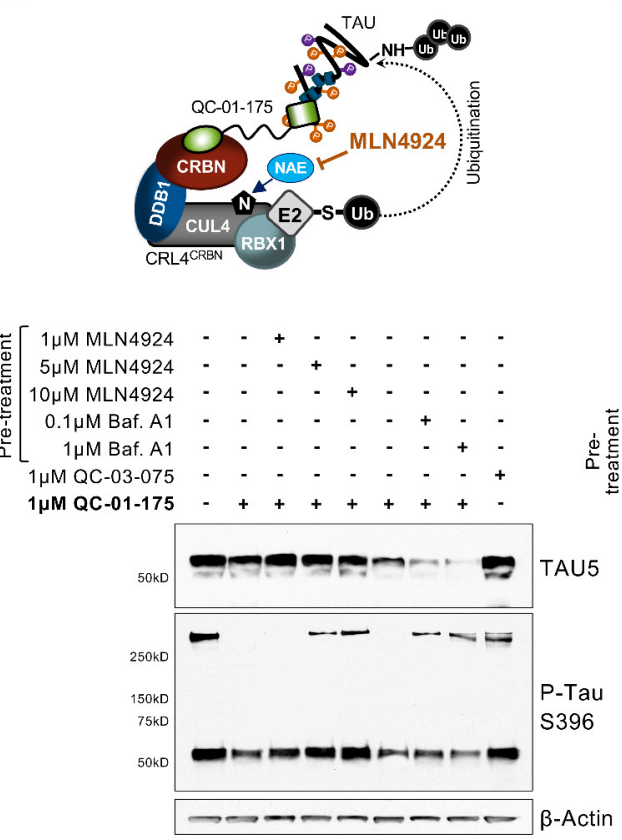

E.

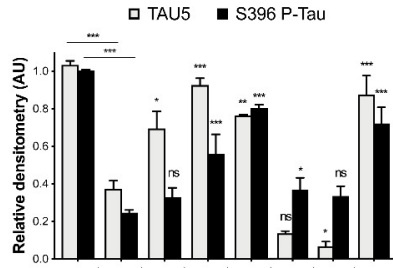

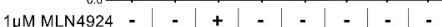

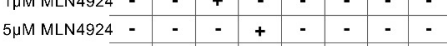

10MM MLN4924 -

$0.1 \mu \mathrm{M}$ Baf. A1

$1 \mu \mathrm{M}$ Baf. A1

1 $\mu \mathrm{M}$ QC-03-075

$1 \mu \mathrm{M} Q \mathrm{QC}-01-175$
C.

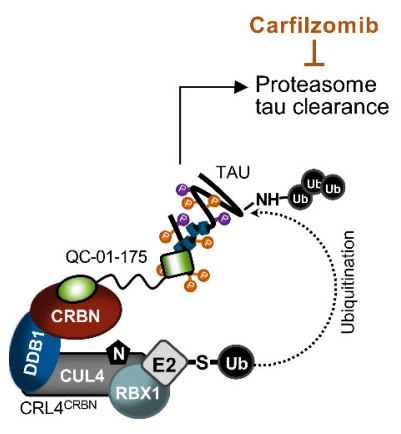

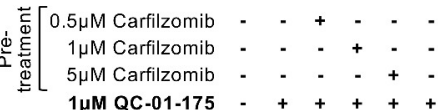

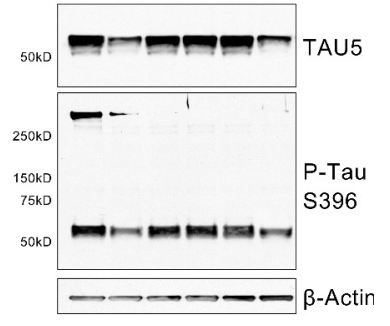

F.

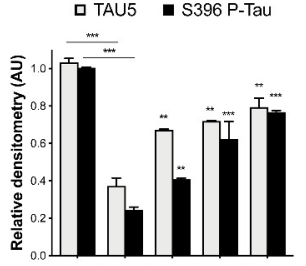

$0.5 \mu \mathrm{M}$ Carfilzomib - $|-|+|+|$

$1 \mu \mathrm{M}$ Carfilzomib -

\begin{tabular}{ll|c|c|c|} 
5HM Carfizomib - & - & - & - & + \\
$1 \mu \mathrm{M}$ QC-01-175 - & + & + & + & +
\end{tabular}

Figure 3. Mechanism of QC-01-175 clearance of tau is CRL4 ${ }^{\mathrm{CRBN}}$ and UPS-dependent. Neurons were pre-treated for $6 \mathrm{hr}$ with (A) either CRBN ligand excess lenalidomide or tau ligand excess T807, (B) the NAE inhibitor MLN4924, the autophagy inhibitor Baf.A1, or (C) the proteasome inhibitor carfilzomib; followed by $18 \mathrm{hr}$ treatment with QC-01-175 (or negative control QC-03-075), for a total of 24 hr. Total (TAU5) and P-tau S396 levels were analyzed by western blotting. (A-C) Representative blots are shown. (D-F) Densitometry bars represent tau mean intensity values \pm SD ( $n=3$ ), relative to vehicle-treated samples. Student T-test of QC-01-175 samples relative to vehicle treated, and the remainder bars show $p$-value of each pretreatment relative to QC-01-175 to assess rescue of clearance effect $\left({ }^{\star \star *} p<0.001,{ }^{\star \star} p<0.01,{ }^{\star} p<0.05,{ }^{n s} p>0.05\right)$. A152T neurons were differentiated for 6 weeks. Figure 3-figure supplement 1 includes additional specificity controls for A152T, P301L and control neuronal models. The following figure supplement is available for Figure 3.

\section{DOI: https://doi.org/10.7554/eLife.45457.010}

The following figure supplement is available for figure 3 :

Figure supplement 1. Additional specificity controls for QC-01-175-mediated tau clearance.

interaction between tau and the CRL4 ${ }^{\text {CRBN }}$ E3 ligase may also occur endogenously in human neurons, as has been reported in tissue from mouse brain (David et al., 2002; Del Prete et al., 2016). Notably, P-tau high-molecular-weight species detected by PHF-1 (see 'flow through' of W:PHF-1, Figure 4A) were not captured by co-IP, which might be caused by bead-antibody alteration of epitope detection or simply low pull-down efficiency of these species in these conditions. Probing with an ubiquitin antibody (W:Ubi-1, Figure 4A) showed an increase in ubiquitinated proteins by QC-01$175 \pm$ carfilzomib treatment, with the same migration as tau $(\sim 50 \mathrm{kDa})$, consistent with a QC-01-175- 
A.

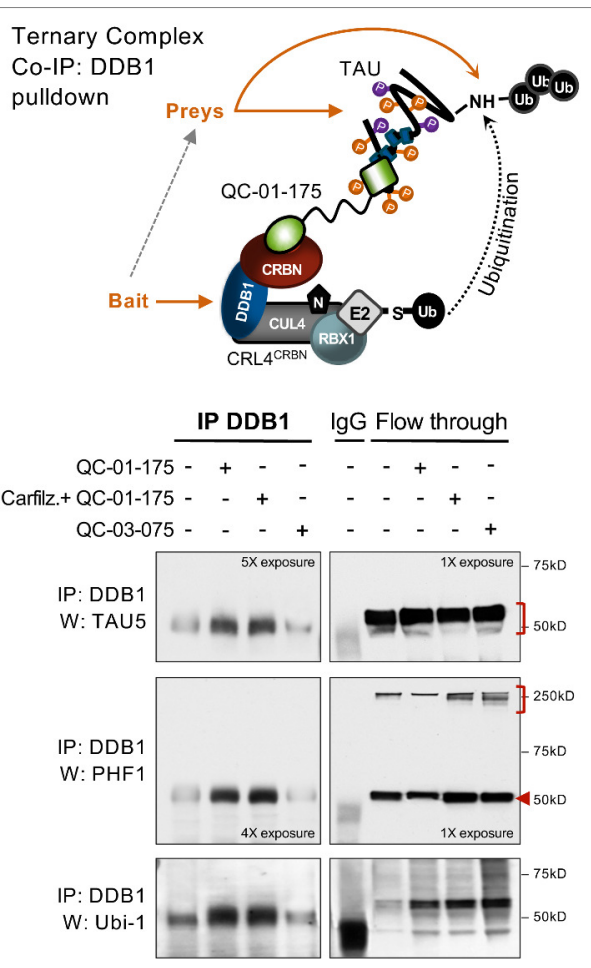

B.

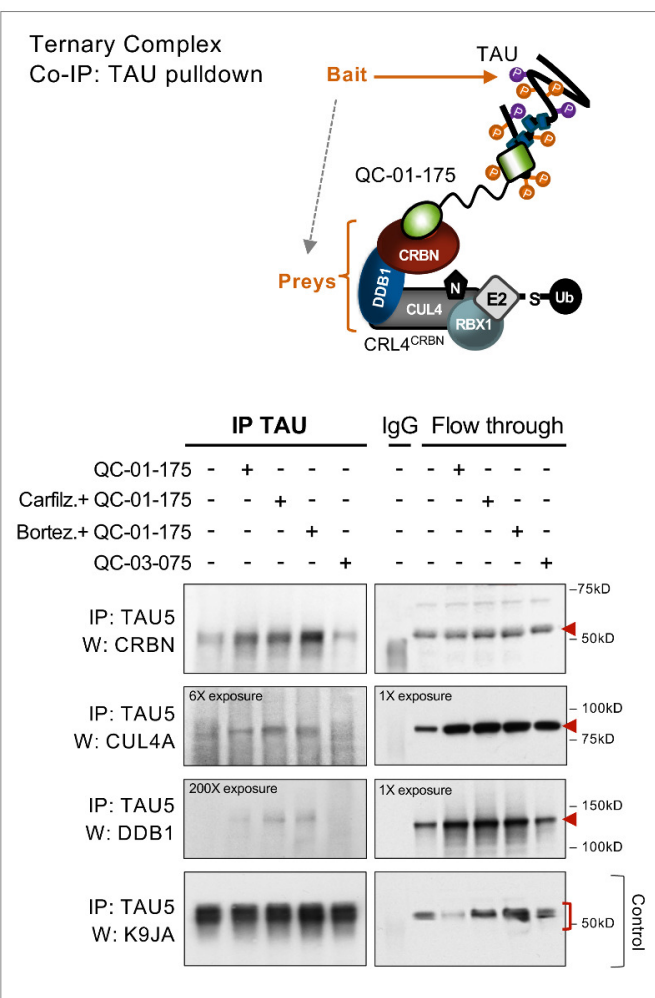

C.

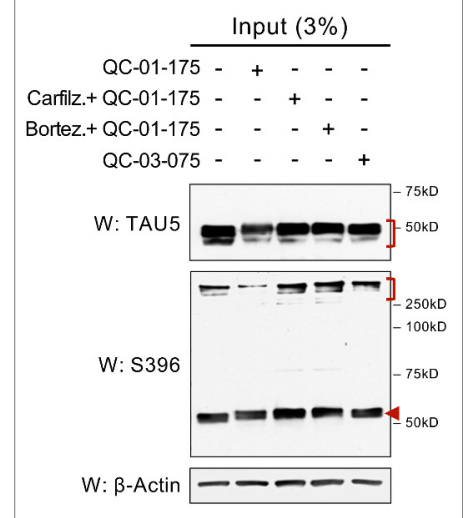

Figure 4. Demonstration of ternary complex formation in A152T neurons upon QC-01-175 treatment, by co-IP and western blot analysis. Neurons (6week differentiated) were treated for $4 \mathrm{hr}$ with $1 \mu \mathrm{M}$ QC-01-175 \pm 30 min pre-treatment with proteasome inhibitors (carfilzomib or bortezomib at $5 \mu \mathrm{M}$ ), with the goal of capturing maximum molecular interactions at $4 \mathrm{hr}$ and halting tau clearance. QC-03-075 is a negative control for CRBN binding. (A) Co-IP by DDB1 pulldown and detection of tau in the complex by probing for total tau (TAU5), P-tau ${ }^{\mathrm{S} 396 / \mathrm{S} 404}$ (PHF-1), and ubiquitinated proteins (Ubi-1). (B) Co-IP by tau pulldown (TAU5) and detection of CRL4 ${ }^{\text {CRBN }}$ subunits CRBN, CUL4A and DDB1. Western blot of total tau (K9JA) was used as a control. (C) Control western blot analysis with 3\% (10 $\mu \mathrm{g})$ of IP input confirms the effect of QC-01-175 \pm proteasome inhibitors on tau and P-tau S396. Red arrows and brackets indicate the predicted bands for each immunoprobed protein $(n=3)$.

mediated increase in tau ubiquitination. Conversely, immunoprecipitation of tau (TAU5 antibody) and western blotting analysis showed co-IP with CRBN in QC-01-175 treated samples \pm carfilzomib or bortezomib (Figure 4B). Again, a low level of CRBN-tau interaction was seen for vehicle and negative control QC-03-075-treated samples. CUL4A and DDB1 were also detected by western blotting, particularly in carfilzomib- and bortezomib-treated samples, but at much lower intensity (Figure 4B). Total tau K9JA western blotting was used as a control of tau IP. In both assays, comparison with flow-through control western blotting (notice film exposures, Figure $4 A, B$ ) shows that coIP'ed proteins were a relatively low fraction of the total cellular amount, which was expected given the assay conditions and the transient nature of E3-ligase:substrate complexes. Differences in antibody sensitivities may also affect detection of each component of CRL4 ${ }^{\mathrm{CRBN}}$ in Figure $4 B$. IP inputonly western blotting analysis confirmed QC-01-175 degradation of tau and P-tau, as well as no effect on tau levels by the vehicle, negative control, or in carfilzomib/bortezomib pre-treated samples (Figure 4C). These results support ternary complex formation between tau, degrader and CRL4 ${ }^{\text {CRBN }}$ followed by increased tau ubiquitination, at the $4 \mathrm{hr}$ time point, providing further evidence of the mechanism of tau clearance by QC-01-175 through E3 ligase function and proteasome degradation. 


\section{Kinetics of tau degradation}

In order to establish the kinetics of tau degradation, we treated A152T (Figure 5, Figure 5-figure supplement $1 \mathrm{~A}-\mathrm{C}$ ) and P301L (Figure 5-figure supplement 1F-H) neurons for 4 or $8 \mathrm{hr}$, and compared tau degradation to the $24 \mathrm{hr}$ treatment time-point using tau ELISA. For A152T neurons, at the $4 \mathrm{hr}$ time-point we observed a sharp hook effect (Huang and Dixit, 2016) (Figure 5-figure supplement $1 \mathrm{~A})$, with maximum clearance of tau and $\mathrm{P}-\operatorname{tau}^{\mathrm{S} 396}\left(\mathrm{D}_{\max }, 4 \mathrm{~h}=80 \%\right)$ at $100 \mathrm{nM}$ (Figure $\left.5 \mathrm{~A}-\mathrm{B}\right)$, constant $50 \%$ degradation at $500 \mathrm{nM}$ and $1 \mu \mathrm{M}$ (Figure $5 \mathrm{C}$ ), and little effect on tau levels at $10 \mu \mathrm{M}$ QC-01-175 (Figure 5D). After $8 \mathrm{hr}$, the hook effect lessened (Figure 5-figure supplement 1B), and $D_{\max }$, 8h of $50 \%$ tau was observed at all concentrations above $100 \mathrm{nM}$ (Figure 5A-D). By comparison, at the $24 \mathrm{hr}$ time-point tau and $\mathrm{P}$-tau ${ }^{\mathrm{S} 396}$ levels were further reduced in a concentrationdependent manner to a $D_{\max }, 24 \mathrm{~h}$ of $70 \%$ at $10 \mu \mathrm{M}$ (Figure 5-figure supplement 1C). The $4 \mathrm{hr}$ effect of QC-01-175 on A152T neurons was corroborated by western blotting analysis (Figure 5figure supplement 1D,E). In P310L neurons, there was more variability between the two tau species at the $4 \mathrm{hr}$ time-point (Figure 5-figure supplement 1F). For total tau, we observed a hook effect with $D_{\max }$, 4h occurring at $100 \mathrm{nM}$, whereas for $\mathrm{P}$-tau ${ }^{5396}$ maximal degradation was observed at 500 $\mathrm{nM}$ (both $D_{\max }, 4 \mathrm{~h}=80 \%$ ). However, by $8 \mathrm{hr}$ robust degradation of tau and $\mathrm{P}$-tau ${ }^{\mathrm{S} 396}(40-50 \%)$ was achieved at all concentrations above $500 \mathrm{nM}$, and $\mathrm{D}_{\max }$, 8h was further increased to $60-70 \%$ by $24 \mathrm{hr}$ (Figure 5-figure supplement 1G,H).

\section{Evaluation of degrader specificity in neurons}

To identify potential off-targets of the QC-01-175 degrader in the A152T neuronal proteome, we employed multiplexed MS-based proteomics to measure changes in protein abundance following a $4 \mathrm{hr}$ treatment. Short treatments, such as this, enable some control over transcriptional and secondary effects that are often a consequence of prolonged drug exposure. Protein abundances were measured using tandem mass tag (TMT) isobaric labels, enabling the quantification of treatment effects with QC-01-175 (active degrader), QC-03-075 (inactive control), and QC-01-175 + MLN4924 (degradation rescue), relative to vehicle control. Whole proteome analysis resulted in the

A.

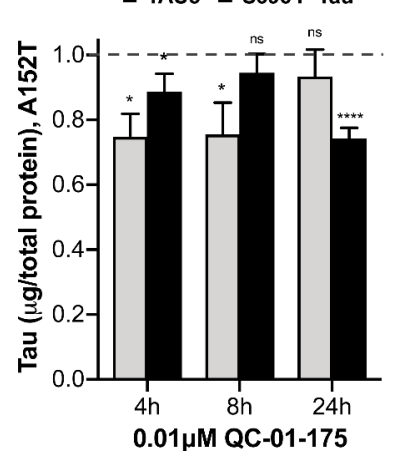

B.

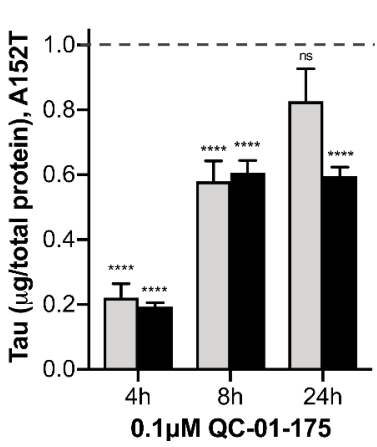

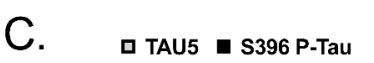

C. 口 TAU5 $\square$ S396 P-Tau

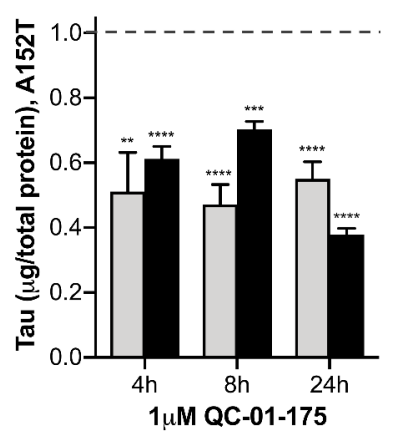

D. $\quad$ TAU5 $\square$ S396 P-Tau

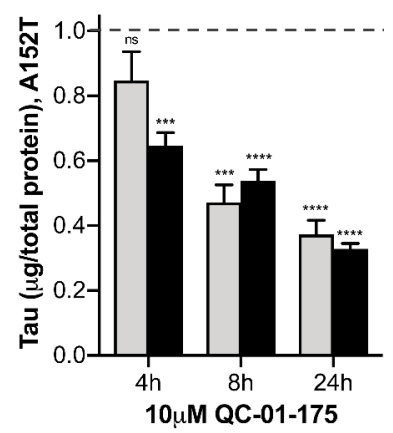

Figure 5. Comparative analysis of the effect of $\mathrm{QC}-01-175$ at (A) $0.01 \mu \mathrm{M},(\mathrm{B}) 0.1 \mu \mathrm{M},(\mathrm{C}) 1 \mu \mathrm{M}$, and (D) $10 \mu \mathrm{M}$ after $4 \mathrm{hr}, 8 \mathrm{hr}$ or $24 \mathrm{hr}$ of treatment. Graph bars represent mean levels of total tau (TAU5) and S396 P-tau protein measured by ELISA, normalized to total $\mu \mathrm{g}$ of protein and to vehicletreated samples \pm SEM $(n=3)$, in A152T 6-week differentiated neurons. Student T-test for each dose/time is relative to vehicle-treated tau levels ${ }^{\text {ns }} p>$ $0.05,{ }^{\star} p<0.05,{ }^{* \star} p<0.01,{ }^{* \star *} p<0.001,{ }^{* \star \star \star} p<0.0001$. Figure 5-figure supplement 1 shows concentration effect curves for QC-01-175 at 4 hr and 8 hr, for all doses tested in A152T and P301L neurons; as well as the $4 \mathrm{hr}$ effect seen by western blot. Figure 5-source data 1 includes all values plotted in the main Figure and supplement. The following figure supplement is available for Figure 5.

DOI: https://doi.org/10.7554/eLife.45457.013

The following source data and figure supplement are available for figure 5 :

Source data 1. Numerical description and statistics for data presented in Figure 5 and respective supplement 1. DOI: https://doi.org/10.7554/eLife.45457.014

Figure supplement 1. Degrader concentration and time effect on tau, in $\mathrm{A} 152 \mathrm{~T}$ and $\mathrm{P} 301 \mathrm{~L}$ neurons. DOI: https://doi.org/10.7554/eLife.45457.015 
identification and quantification of $>8000$ proteins with summed signal:noise $>200$ and $>2$ unique peptides. Upon $4 \mathrm{hr}$ treatment with $1 \mu \mathrm{M}$ QC-01-175, the only significant changes observed comprise the validated immune-modulatory drug (IMiD) targets ZFP91, ZNF653 and ZNF827 (Donovan et al., 2018), while no QC-01-175 specific off-targets were observed (Figure 6A). Degradation of these $\mathrm{C}_{2} \mathrm{H}_{2}$ zinc finger transcription factors was expected as an off-target response to the CRBN-binding module of OC-01-175 (pomalidomide, Figure 1C). Conversely, the negative control QC-03-075 $(1 \mu \mathrm{M})$ revealed no effect on these proteins, confirming the ablation of CRBN-binding activity (Figure 6B). The degradation rescue experiment, consisting of pre-treatment with the neddylation inhibitor MLN4924 (inhibits activation of all NEDD8-dependent CRL) (Lan et al., 2016) and QC-01-175, showed a complete rescue of IMiD target degradation, confirming the neddylation and hence cullin-dependence for target degradation (Figure $6 \mathrm{C}$ ). These results confirmed that QC-01175 has minimal off-target activity. We were unable to reliably quantify tau by proteomics since the solubilization procedure necessary to dissolve insoluble tau species is incompatible with our pipeline.

\section{QC-01-175 rescues tau-mediated stress vulnerability of FTD neurons}

In FTD patient-derived neuronal cell models, accumulation of tau and P-tau of reduced solubility is coupled to increased cellular vulnerability to specific forms of stress (Silva et alo, 2016). One of these stressors is the proteotoxicity caused by the highly aggregation-prone peptide $A \beta(1-42)$, which promotes a concentration-dependent loss of viability in A152T and P301L neurons (Figure 7A). This effect on viability is not seen in WT control neurons and can be rescued by CRISPR/Cas9-mediated MAPT knockout (KO) in A152T neurons (Figure 7A) (Silva et al., 2016). We tested whether QC-01175 could similarly protect against tau-mediated stress vulnerability and loss of viability. A152T neurons were pre-treated with either $5 \mu \mathrm{M}$ QC-01-175 or $5 \mu \mathrm{M}$ OC-03-075 (Figure 7B b), or vehicle alone (DMSO, Figure $7 B$ c) for $8 \mathrm{hr}$, followed by addition of $10 \mu \mathrm{M} \mathrm{A} \beta(1-42)$ stressor for an additional $16 \mathrm{hr}$ (Figure $7 B \mathrm{~b}, \mathrm{c}$ ). Vehicle- and degrader-only treated samples were also included as controls (Figure $7 B$ a). Vehicle pre-treated neurons followed by $A \beta(1-42)$ treatment loss $50 \%$ viability at the $24 \mathrm{hr}$ time-point (Figure 7C). OC-01-175 pre-treatment rescued viability to $90 \%$ of vehicle-alone control, almost phenocopying the $100 \%$ viability rescue observed in MAPT KO neurons (Figure 7C).

A.

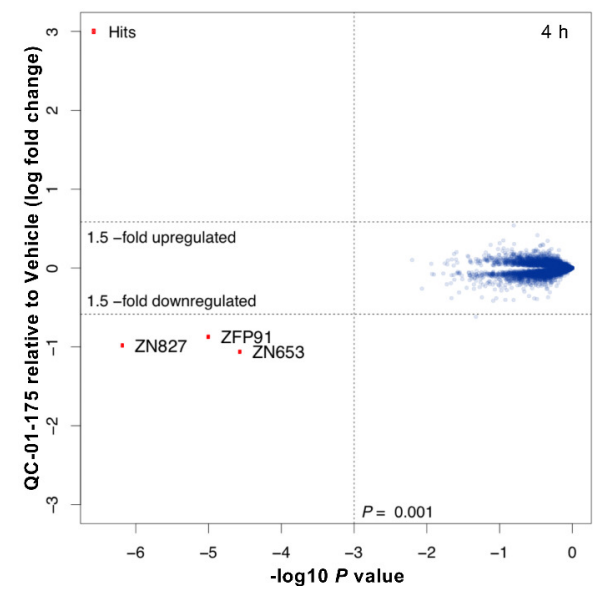

B.

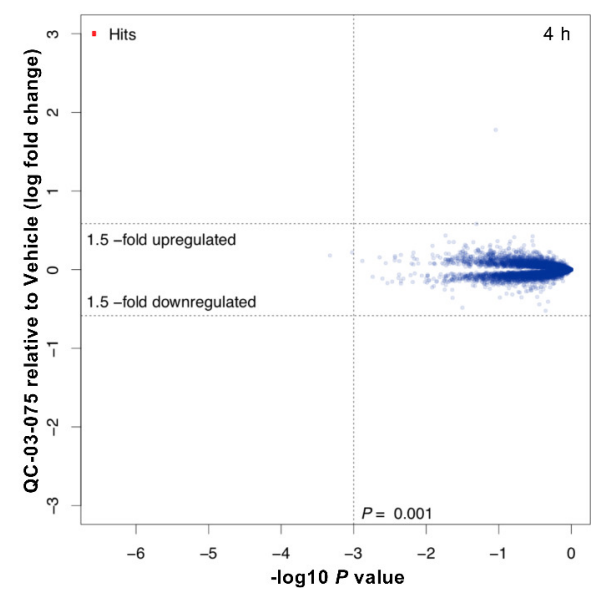

C.

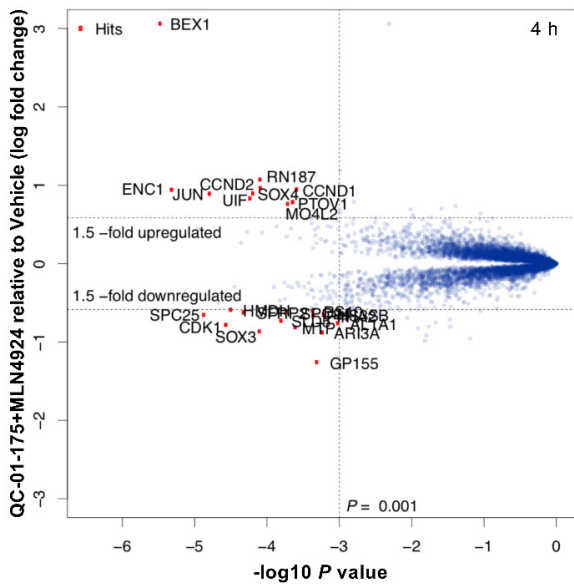

Figure 6. Mass spectrometry-based proteomics to quantify the effect of QC-01-175 treatment on the proteome of A152T neurons. 6-week differentiated neurons were treated for $4 \mathrm{hr}$ with (A) $1 \mu \mathrm{M}$ of $\mathrm{QC}-01-175$, (B) $1 \mu \mathrm{M}$ of the negative control OC-03-075, or (C) 10 $\mu \mathrm{M}$ MLN4924 (NAE inhibitor, 30 min pre-treatment) and $1 \mu \mathrm{M}$ of QC-01-175. Upon degrader QC-01-175 treatment (A), three off-targets were detected within statistical significance, which all belong to known IMiD targets, an effect rescued by the negative control (B) or inhibition of neddylation by MLN4924 (C). Significant hits were assessed by moderated t-test as implemented in the limma package (Ritchie et alo, 2015), with the log2 fold change shown on the $y$-axis, and negative $\log 10 P$ values on the $x$-axis ( $n=3$ for treatment with DMSO, QC-01-175, and QC-03-075, and $n=2$ for QC-01-175 + MLN4924). DOI: https://doi.org/10.7554/eLife.45457.016 
A.

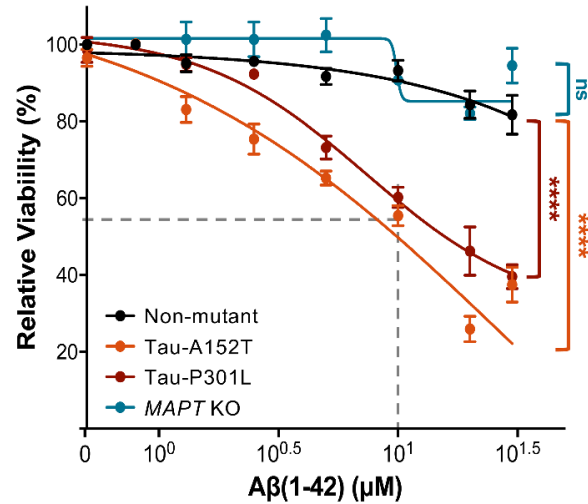

B.

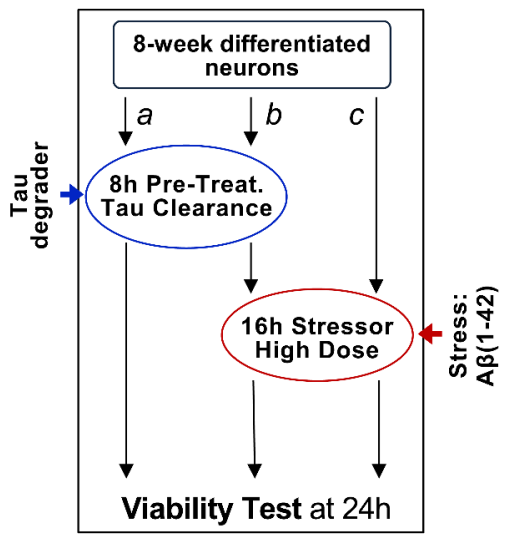

C.
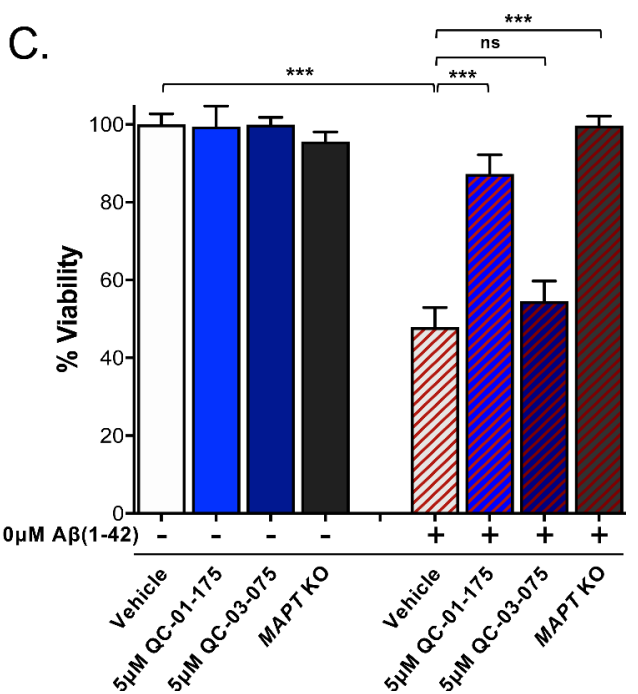

Figure 7. $\mathrm{QC}-01-175$ treatment rescued stress vulnerability of $A 152 T$ neurons. (A) A $(1-42)$ proteotoxicity causes concentration- and genotypedependent loss of neuronal vulnerability, affecting preferentially A152T and P301L neurons, with a rescue by MAPT KO. Data points represent mean viability relative to vehicle-treated neurons (100\%) \pm SEM $(n \geq 3)$; two-way ANOVA statistical analysis relative to non-mutant control-1 neurons (black curve, 8330-8-RC1), ${ }^{* \star *} p<0.0001,{ }^{n s} p>0.05$. (B) Assay overview to measure effect of the stressor $A \beta(1-42)$ on neuronal viability (c) and potential rescue by pre-treatment with QC-01-175 (b). Effect of $24 \mathrm{hr}$ treatment with QC-01-175 alone was also tested (a). (C) QC-01-175 (light blue-stripe bar) but not the negative control QC-03-075 (dark blue-stripe bar), rescued viability loss caused by A $\beta(1-42)$ (white-stripe bar) in A152T neurons differentiated for 8 weeks, in a comparable manner to genetic MAPT knockout (black-stripe bar). Graph bars represent mean \% viability \pm SD, relative to vehicle-treated (white) neurons. T-test ${ }^{* *} \mathrm{p} \leq 0.001 ;{ }^{n s} \mathrm{p}>0.05(n=3)$. Figure 7-source data 1 includes all values plotted in main Figure 7A and $C$.

DOI: https://doi.org/10.7554/eLife.45457.017

The following source data is available for figure 7 :

Source data 1. Numerical description and statistics for data presented. DOI: https://doi.org/10.7554/eLife.45457.018

The negative control QC-03-075 had little effect on the toxicity of $A \beta(1-42)$. As expected, $24 \mathrm{hr}$ treatment with either $\mathrm{QC}-01-175$ or negative control alone caused no change in neuronal viability (Figure 7C, left blue bars).

In conclusion, the tau degrader QC-01-175 triggers proteasome-dependent tau and P-tau clearance in FTD patient-derived neurons, which is able to rescue tau-mediated toxicity in biologically relevant assays of stress vulnerability.

\section{Discussion}

In this study, we established that disease-relevant forms of tau and P-tau in FTD patient-derived neuronal cell models are amenable to targeted degradation and characterize the tool compound QC01-175 as an effective tau degrader. We developed a BLI in vitro assay to assess QC-01-175 binding to recombinant tau species relative to T807. Despite detecting binding, QC-01-175 and T807 showed micromolar affinities to immobilized, soluble protein, independent of the presence of a tau variant. E. coli-expressed and purified recombinant human tau has distinct properties that are not reflective of intracellular protein conformations, which may be key to the recognition, binding and degradation of tau by QC-01-175 in the neuronal context. This is a limitation of current heterologous cell culture systems and in vitro measurements that do not recapitulate endogenous cellular tau properties. This highlights the importance of assaying disease-relevant tau species and an urgent need for improved biophysical binding assays. Introducing patient-specific neuronal models that recapitulate early aspects of tau pathology ex vivo in a drug discovery pipeline is unique to this study. Human stem cell-derived neurons allow access to physiologically relevant cell types and protein complexes, offering the advantage of modeling pathogenic tau species without the need for 
overexpression of heterologous genes, in the context of the patient genomic background (Dolmetsch and Geschwind, 2011; Silva et al., 2017; Wan et al., 2015; Chesselet and Carmichael, 2012). QC-01-175 was able to promote tau clearance in FTD neurons expressing tau-A152T or tau$\mathrm{P} 301 \mathrm{~L}$, in a concentration-dependent manner, and subsequently rescued tau-mediated neuronal stress vulnerability. The effect of QC-01-175 in A152T and P301L heterozygous neurons led on average to more than $70 \%$ and $60 \%$ clearance of tau, respectively, when only about $50 \%$ of tau expressed has the variant. This is informative regarding the species of tau targeted by the degrader, raising the hypothesis that some forms of non-mutant tau in FTD neurons are also misfolded and targeted for degradation. Remarkably, the degrader preferentially targeted tau species from FTD neurons, with minimal effect on tau from unaffected WT control neurons. This indicates that it may be possible to develop tau-degrader therapies that selectively act in FTD-affected neurons, and on disease-associated forms of tau, independent of genotype, and spare normal tau protein within the affected regions of the brain.

Variation in QC-01-175-mediated tau degradation dose profiles between A152T and P301L neurons (Figure 2C and Figure 2-figure supplement 2A) points to differences in tau species originated by the two tau variants, and possibly also differences in proteostasis for the two patientderived cell models, which affects UPS function. This aspect will impact the clinical translational potential of any degrader targeting tau to the proteasome, which has been demonstrated to be affected by neurodegeneration and aging itself (Deger et al., 2015; Keck et al., 2003; Saez and Vilchez, 2014). This, however, does not preclude the development of targeted degraders as therapeutic strategies for early stage disease, or as a co-therapeutic with proteasome activity chemical enhancers (Myeku and Duff, 2018). Notably, co-IP results (Figure 4) suggest that there is a basal level of interaction between tau and the CRL4 ${ }^{\text {CRBN }}$ E3 ligase in A152T neurons. Interestingly, Del Prete et al. reported that tau could be a natural substrate of CRBN through a complex involving the amyloid precursor protein (APP), mutations in which are known to cause AD (Del Prete et al., 2016). The co-IP experiment data we present here indicates that in FTD there may also be some basal tau: CRBN association, and thus, rather than targeting a 'neo-substrate', QC-01-175 may be promoting efficacy of a physiological process, increasing the probability of successful tau degradation in vivo. Further work is needed to investigate this hypothesis.

Important challenges still remain for translation of our promising initial findings into a therapeutic. From a pharmacology standpoint, $\mathrm{QC}-01-175$ is a relatively large and flexible molecule compared to most brain-active drugs and may suffer from fast metabolism and poor brain penetration. Tuning pharmacology for in vivo applications is an ongoing challenge in the targeted protein degradation field, but progress is being made (Gu et al., 2018). If this tuning proves intractable, intrathecal administration could be considered. Clinical biomarkers for target engagement and efficacy evaluation will also be critical. Since QC-01-175 occupies the binding site of a PET ligand, it might be possible to use PET to measure target engagement in vivo. However, because degraders can act catalytically, their pharmacodynamics may influence and complicate PET readings. Further evaluation of QC-01-175 off-target binding will also be crucial. The degrader can recognize and downregulate other proteins as shown here by mass spectrometry global proteome analysis (Figure 6A), where three $\mathrm{C}_{2} \mathrm{H}_{2}$ zinc finger transcription factors were downregulated by a $4 \mathrm{hr}$ treatment with $\mathrm{QC}-01-$ 175. This off-target activity likely arises from the CRBN-binding module of QC-01-175 (pomalidomide, Figure 1C), which has been reported to induce degradation of multiple members of the $\mathrm{C}_{2} \mathrm{H}_{2}$ zinc finger protein family through a 'molecular glue' type mechanism (Sievers et al., 2018). Since these are lesser-known transcription factors, the cellular implications of their degradation are not yet fully understood. Using what is known about IMiD-based degrader design, efforts to design next generation tau degraders will involve tuning the attachment chemistry to replace the aniline nitrogen, and altering the degrader linker composition to remove these IMiD off-target effects (Nowak et al., 2018; Dobrovolsky et al., 2019; Jiang et al., 2019), thus creating a tau-selective degrader. These efforts are currently underway in our laboratory. However, QC-01-175 may also have modulatory effect on function/activity of other proteins without leading to degradation. Here, we tested and excluded the known MAO inhibitory effect of T807, but one could speculate that other enzymes (e.g. kinases) could be affected in vivo. Therefore, a detailed profiling of off-target binding interactions is a necessary future investigative effort. Finally, since it is now possible to routinely establish patient specific iPSC-derived neuronal cultures, an interesting strategy for clinical trial success might be to screen individual patients for responsiveness using cellular models. 
In conclusion, here we have established a neurodegeneration-specific workflow for development of targeted degraders for aggregation-prone proteins. Our workflow leveraged existing PET probe binders in degrader design, and well-characterized patient-derived neuronal models to assay against clinically relevant protein species and phenotypes. These efforts yielded QC-01-175, a valuable new research tool for the study of tau-mediated events in human tauopathies. PET-tracer-based heterobifunctional degrader design and patient-derived cellular models offer an unprecedented advantage for the targeting of pathologically relevant tau species, relative to in vitro and heterologous expression systems. Additionally, we anticipate that future advances in understanding the relationship between tau post-translational modifications and adopted conformations in disease, as well as visualizing and modeling interactions between tau and various PET tracers, will aid in the knowledgebased design of next generation targeted degraders. Importantly, our approach may be generalizable to other proteinopathies where high-quality PET tracers and cellular models are available. In this context, our study suggests that small-molecule-mediated protein degradation represents a promising strategy to advance our understanding of human neurodegenerative disease and translate those insights into targeted therapies.

\section{Materials and methods}

Key resources table

Reagent type (species) or resource

Cell line (H. sapiens)
Designation
8330-8-RC1
Source or reference

Silva et al. (2016)

Stem Cell Reports.
Identifiers

Additional information

Figure 2-source data 1 Human iPSC-derived NPC line, non-mutant tau. Original fibroblasts GM08330 from Coriell Institute for Medical Research.

\begin{tabular}{ll}
\hline Cell line (H. sapiens) $\quad$ MGH2069-RC1 & Seo et al. (2017) J. \\
& Neuroscience. Manuscript \\
in preparation.
\end{tabular}

Figure 2-source data 1 Human iPSC-derived NPC line, non-mutant tau. Original fibroblasts MGH-2069 from Massachusetts General Hospital Frontotemporal Dementia Clinic, Massachusetts General Hospital Neurodegeneration Repository.

\begin{tabular}{lll}
\hline Cell line (H. sapiens) & CTR2-L17-RC2 & Almeida et al., 201 \\
& & $\begin{array}{l}\text { Reports. Silva et al. } \\
\text { Stem Cell Reports }\end{array}$ \\
\hline Cell line (H. sapiens) & FTD19-L5-RC6 & Silva et al. (2016) \\
& & Stem Cell Reports
\end{tabular}

Cell line (H. sapiens)

FTD19-L5-RC6;MAPT-KO

Silva et al. (2016)

Stem Cell Reports
Figure 2-source data 1. Human iPSC-derived NPC line, non-mutant tau.

Figure 2-source data 1. Human iPSC-derived NPC line, tau-A152T (NCBI RefSeq NM_001123066; rs143624519).

Figure 2-source data 1 Human iPSC-derived NPC FTD19-L5-RC6 line, CRISPR/Cas9-engineered MAPT knockout.

Figure 2-source data 1 Human iPSC-derived NPC line, tau-P301L (NCBI RefSeq NM_001123066; rs63751273). Original fibroblasts MGH-2046 from Massachusetts General Hospital Frontotemporal Dementia Clinic, Massachusetts General Hospital

Neurodegeneration Repository. 
Continued

\begin{tabular}{|c|c|c|c|c|}
\hline $\begin{array}{l}\text { Reagent type (species) } \\
\text { or resource }\end{array}$ & Designation & Source or reference & Identifiers & Additional information \\
\hline Antibody & TAU5 & Invitrogen & $\begin{array}{l}\text { Cat. AHB0042 } \\
\text { RRID:AB_2536235 }\end{array}$ & WB 1:1000 \\
\hline Antibody & TAU5 & AbCam & $\begin{array}{l}\text { Cat. ab80579 } \\
\text { RRID:AB_1603723 }\end{array}$ & Co-IP \\
\hline Antibody & Tau K9JA & DAKO, Agilent & Cat. A002401-2 & IF 1:1000, WB 1:10,000 \\
\hline Antibody & P-Tau S396 & Invitrogen & $\begin{array}{l}\text { Cat. 44752G } \\
\text { RRID:AB_1502108 }\end{array}$ & WB 1:1000 \\
\hline Antibody & P-Tau PHF-1 & Dr. Peter Davies & $\begin{array}{l}\text { Albert Einstein } \\
\text { College of Medicine, NY }\end{array}$ & IF 1:400 \\
\hline Antibody & MAP2 & $\begin{array}{l}\text { Chemicon, } \\
\text { Millipore }\end{array}$ & $\begin{array}{l}\text { Cat. AB5543 } \\
\text { RRID:AB_571049 }\end{array}$ & IF 1:1000 \\
\hline Antibody & DDB1 & AbCam & $\begin{array}{l}\text { Cat. ab109027 } \\
\text { RRID:AB_10859111 }\end{array}$ & WB 1:50,000/Co-IP \\
\hline Antibody & CUL4A & $\begin{array}{l}\text { Cell Signaling } \\
\text { Technology }\end{array}$ & $\begin{array}{l}\text { Cat. } 2699 \\
\text { RRID:AB_2086563 }\end{array}$ & WB 1:1000 \\
\hline Antibody & CRBN & ProteinTech & $\begin{array}{l}\text { Cat. 11435-1-AP } \\
\text { RRID:AB_2085739 }\end{array}$ & WB 1:500 \\
\hline Antibody & Ubiquitin, Ubi-1 & Millipore & $\begin{array}{l}\text { Cat. MAB1510 } \\
\text { RRID:AB_2180556 }\end{array}$ & WB 1:500 \\
\hline Antibody & $\beta$-Actin & Sigma-Aldrich & $\begin{array}{l}\text { Cat. A1978 } \\
\text { RRID:AB_476692 }\end{array}$ & WB 1:10,000 \\
\hline Antibody & GAPDH & AbCam & $\begin{array}{l}\text { Cat. ab8245 } \\
\text { RRID:AB_2107448 }\end{array}$ & WB 1:5000 \\
\hline Antibody & $\begin{array}{l}\text { AlexaFluor- } 4882^{\circ} \\
\text { antibody }\end{array}$ & Life Technologies & $\begin{array}{l}\text { Cat. A11039 } \\
\text { RRID:AB_142924 }\end{array}$ & IF 1:500 \\
\hline Antibody & $\begin{array}{l}\text { AlexaFluor-594 } 2^{\circ} \\
\text { antibody }\end{array}$ & Life Technologies & $\begin{array}{l}\text { Cat. A11012 } \\
\text { RRID:AB_141359 }\end{array}$ & IF 1:500 \\
\hline Antibody & $\begin{array}{l}\text { AlexaFluor-594 } 2^{\circ} \\
\text { antibody }\end{array}$ & Life Technologies & $\begin{array}{l}\text { Cat. A11032 } \\
\text { RRID:AB_141672 }\end{array}$ & IF 1:500 \\
\hline Antibody & $\begin{array}{l}\text { Anti-mouse lgG, } \\
\text { HRP-linked }\end{array}$ & $\begin{array}{l}\text { Cell Signaling } \\
\text { Technology }\end{array}$ & $\begin{array}{l}\text { Cat. 7076S } \\
\text { RRID:AB_330924 }\end{array}$ & Western blotting, 1:4000 \\
\hline Antibody & $\begin{array}{l}\text { Anti-rabbit lgG, } \\
\text { HRP-linked }\end{array}$ & $\begin{array}{l}\text { Cell Signaling } \\
\text { Technology }\end{array}$ & $\begin{array}{l}\text { Cat. 7074S } \\
\text { RRID:AB_2099233 }\end{array}$ & Western blotting, 1:4000 \\
\hline Antibody & Hoechst 33342 & Invitrogen & Cat. H3570 & IF Nuclear stain, 1:1000 \\
\hline $\begin{array}{l}\text { Peptide, Recombinant } \\
\text { Protein }\end{array}$ & $\begin{array}{l}\text { Tau-441(WT), } \\
\text { Biotinylated }\end{array}$ & SignalChem & $\begin{array}{l}\text { Cat. T08-54BN } \\
\text { Lot. H2681-10 }\end{array}$ & $\begin{array}{l}\text { Human recombinant } \\
\text { protein expressed in } \\
\text { E. coli cells. }\end{array}$ \\
\hline $\begin{array}{l}\text { Peptide, Recombinant } \\
\text { Protein }\end{array}$ & Tau-441(A152T) Protein & SignalChem & $\begin{array}{l}\text { Cat. T08-56VN } \\
\text { Lot. B2157-7 }\end{array}$ & $\begin{array}{l}\text { Human recombinant } \\
\text { protein expressed in } \\
\text { E. coli cells, tag-free. } \\
\text { Accession no. P10636-8. }\end{array}$ \\
\hline $\begin{array}{l}\text { Peptide, Recombinant } \\
\text { Protein }\end{array}$ & Tau-441(P301L) Protein & SignalChem & $\begin{array}{l}\text { Cat. T08-56FN } \\
\text { Lot. O917-2 }\end{array}$ & $\begin{array}{l}\text { Human recombinant } \\
\text { protein expressed in } \\
\text { E. coli cells, tag-free. } \\
\text { Accession no. P10636-8. }\end{array}$ \\
\hline $\begin{array}{l}\text { Peptide, Recombinant } \\
\text { Protein }\end{array}$ & $A \beta(1-42)$ & Enzo Lifesciences & Cat. ALX-151-002 & CAS No. 107761-42-2 \\
\hline Commercial Assay, Kit & $\begin{array}{l}\text { EZ-Link } \\
\text { NHS-PEG }{ }_{4} \text {-Biotinylation Kit }\end{array}$ & $\begin{array}{l}\text { Thermo Fisher } \\
\text { Scientific }\end{array}$ & Cat. 21455 & \\
\hline Commercial Assay, Kit & MAO-Glo Assay Kit & Promega & Cat. V1401 & \\
\hline Commercial Assay, Kit & $\begin{array}{l}\text { Pierce BCA Protein } \\
\text { Assay Kit }\end{array}$ & $\begin{array}{l}\text { Thermo Fisher } \\
\text { Scientific }\end{array}$ & Cat. 23227 & \\
\hline Commercial Assay, Kit & Human Total Tau ELISA & Invitrogen & Cat. KHB0041 & \\
\hline
\end{tabular}

Continued on next page 
Continued

Reagent type (species) or resource

Commercial Assay, Kit

Commercial Assay, Kit

Commercial Assay, Kit

Kit Dynabeads Protein G

Commercial Assay, Kit

Commercial Assay, Kit

Commercial Assay, Kit

Viability Reagent

Chemical Compound, Drug T807 (AV-1451)

Chemical Compound, Drug T807 core scaffold

Chemical Compound, Drug Pomalidomide

Chemical Compound, Drug Lenalidomide

Chemical Compound, Drug QC-01-175

Chemical Compound, Drug QC-03-075

This paper

Chemical Compound, Drug MLN4924

Chemical Compound, Drug Bafilomycin A1

Chemical Compound, Drug Carfilzomib

Chemical Compound, Drug Bortezomib

Chemical Compound, Drug PE859

Chemical Compound, Drug Parnate

(Tranylcypromine)

Chemical Compound, Drug Protease inhibitor cocktail

Chemical Compound, Drug Phosphatase inhibitor cocktail 2

Software, Algorithm Data Acquisition HT 11.0

Software, Algorithm

Adobe Photoshop CS5

Software, Algorithm

GraphPad Prism

Software, Algorithm

Proteome Discoverer 2.2

Software, Algorithm

$\mathrm{R}$ framework

Software, Algorithm

Statistical Analysis
Limma Package

(R framework)

Invitrogen

Invitrogen

Novex, Life

Scientific

Scientific

Scientific

This paper
Source or reference Identifiers

Additional information

Cat. KHB7031

Cat. FNN0011

Technologies

Thermo Fisher

(TMT) reagents Thermo Fisher

Thermo Fisher Cat. DAL1025

MedChem Express Cat. HY-101184

(Intermediate 10)

This paper (Intermediate 10)

Cat. P0018

Sigma Aldrich

Cat. 901558

Sigma Aldrich

\begin{tabular}{ll} 
MedChem Express & Cat. HY-70062 \\
\hline Enzo LifeSciences & Cat. BML-CM \\
MedChem Express & Cat. HY-10455 \\
Selleckchem & Cat. S1013 \\
MedChem Express & Cat. HY-12662 \\
$\begin{array}{l}\text { Sigma-Aldrich } \\
\text { Roche }\end{array}$ & Cat. P8511 \\
$\begin{array}{l}\text { Sigma-Aldrich } \\
\text { ForteBio } \\
\text { (www.fortebio.com/octet- } \\
\text { software.html) }\end{array}$ & Cat. P5726 693124
\end{tabular}

Adobe Photoshop

(www.adobe.com/

Photoshop)

GraphPad Prism

(www.graphpad.com)

Thermo Fisher Scientific

Team RCR: A Language

and Environment for

Statistical Computing

http://www.R-project.org/;

accessed Nov. 1, 2017

Bioconductor

Ritchie et al. (2015)

Nucleic Acids Res.
CAS No. 1415379-56-4

Methods, Synthetic methods general protocols. Figure 1C.

CAS No. 19171-19-8

CAS No. 191732-72-6

Methods, Synthetic

methods general protocols. Figure 1C.

Methods, Synthetic methods general protocols. Figure $1 \mathrm{C}$.

CAS No. 905579-51-3

CAS No. 88899-55-2

CAS No. 868540-17-4

CAS No. 179324-69-7

CAS No. 1402727-29-0

CAS No. $1986-47-6$

(BLI Analysis and $\mathrm{K}_{\mathrm{D}}$ calculation)

Version 12.0.4

(Histogram function, western blots densitometry)

Version 8

Version 2.2

R Version 3.5.1

- Feather Spray
Version 11

\section{Continued on next page}


Continued

\begin{tabular}{|c|c|c|c|c|}
\hline $\begin{array}{l}\text { Reagent type (species) } \\
\text { or resource }\end{array}$ & Designation & Source or reference & Identifiers & Additional information \\
\hline Other & Octet Red384 Instrument & ForteBio & & $\begin{array}{l}\text { https://www.fortebio } \\
\text {.com/octet-red384.html }\end{array}$ \\
\hline Other & $\begin{array}{l}\text { IN Cell Analyzer } 6000 \text { Cell } \\
\text { Imaging System }\end{array}$ & $\begin{array}{l}\text { GE Healthcare Life } \\
\text { Sciences }\end{array}$ & & \\
\hline Other & $\begin{array}{l}\text { EnVision Multilabel } \\
\text { Plate Reader }\end{array}$ & Perkin Elmer & & \\
\hline Other & HPLC & Waters 2489/2545 & & \\
\hline Other & UPLC & Waters Aquity I UPLC & & \\
\hline Other & HPLC & $\begin{array}{l}\text { Agilent } 1260 \text { Infinity II } \\
\text { LC System }\end{array}$ & & \\
\hline Other & $\begin{array}{l}\text { Orbitrap Fusion } \\
\text { Lumos mass spectrometer }\end{array}$ & Thermo Fisher Scientific & IQLAAEGAAPFADBMBHQ & \\
\hline Other & $\begin{array}{l}\text { Proxeon EASY-nLC } 1200 \\
\text { LC pump }\end{array}$ & Thermo Fisher Scientific & LC140 & \\
\hline Other & $\begin{array}{l}\text { EasySpray ES803 } 75 \mu \mathrm{m} \\
\text { inner diameter } \\
\text { microcapillary column }\end{array}$ & Thermo Fisher Scientific & ES803 & \\
\hline
\end{tabular}

\section{General protocols}

Unless otherwise noted, reagents and solvents were obtained from commercial suppliers and were used without further purification. ${ }^{1} \mathrm{H}$ NMR spectra were recorded on $500 \mathrm{MHz}$ Bruker Avance III spectrometer, and chemical shifts are reported in parts per million (ppm, $\delta$ ) downfield from tetramethylsilane (TMS). Coupling constants $(\mathrm{J})$ are reported in $\mathrm{Hz}$. Spin multiplicities are described as $\mathrm{s}$ (singlet), br (broad singlet), d (doublet), t (triplet), q (quartet), and m (multiplet). Mass spectra were obtained on a Waters Acquity UPLC. Preparative HPLC was performed on a Waters Sunfire C18 column $(19 \mathrm{~mm} \times 50 \mathrm{~mm}, 5 \mu \mathrm{M})$ using a gradient of $15-95 \%$ methanol in water containing $0.05 \%$ trifluoroacetic acid (TFA) over $22 \mathrm{~min}$ (28 min run time) at a flow rate of $20 \mathrm{~mL} / \mathrm{min}$. Assayed compounds were isolated and tested as TFA salts. Purities of assayed compounds were in all cases greater than $95 \%$, as determined by reverse-phase HPLC analysis.
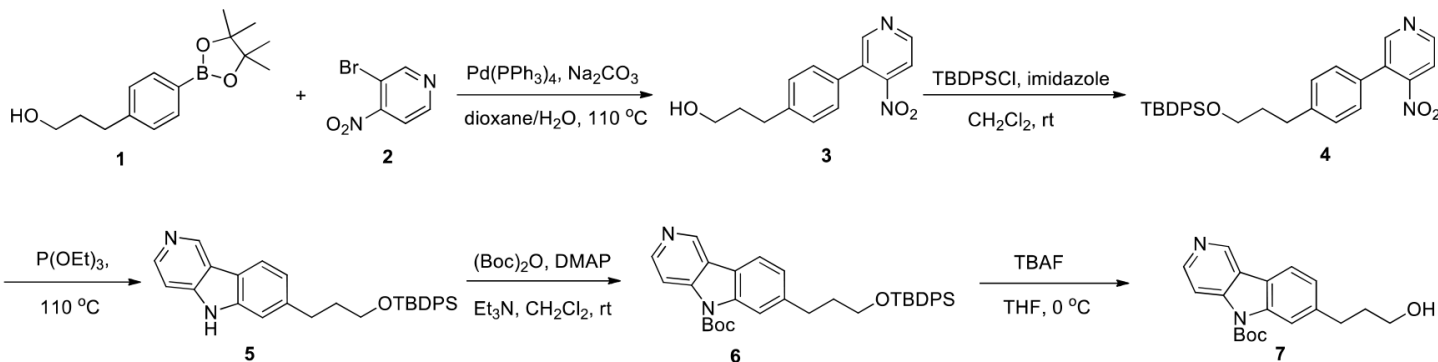
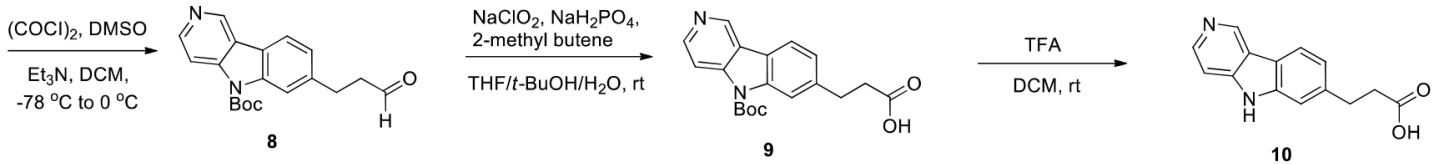

10

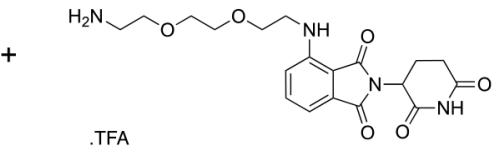

11

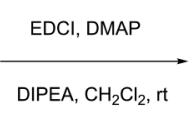

$4^{N}$

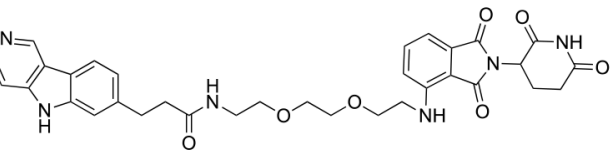

QC-01-175

Scheme 1. Synthesis route for the tau degrader QC-01-175.

DOl: https://doi.org/10.7554/eLife.45457.019 


\section{Synthetic procedures}

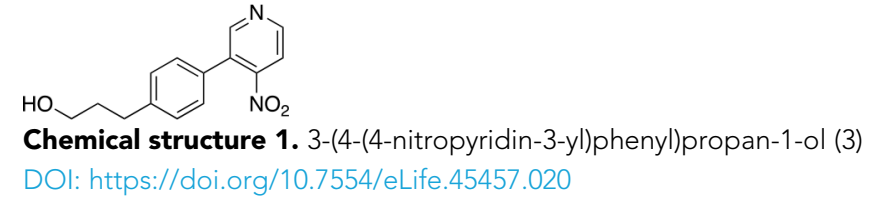

A solution of $1(1.65 \mathrm{~g}, 6.29 \mathrm{mmol}), 2(1.16 \mathrm{~g}, 5.72 \mathrm{mmol}), \mathrm{Na}_{2} \mathrm{CO}_{3}(1.52 \mathrm{~g}, 14.3 \mathrm{mmol})$ and $\mathrm{Pd}$ $\left(\mathrm{PPh}_{3}\right)_{4}(330 \mathrm{mg}, 0.286 \mathrm{mmol})$ in 1,4-dioxane $(40 \mathrm{~mL})$ and $\mathrm{H}_{2} \mathrm{O}(10 \mathrm{~mL})$ was stirred at $110^{\circ} \mathrm{C}$ for $16 \mathrm{hr}$ before it was quenched with $\mathrm{NH}_{4} \mathrm{Cl}$ (sat. aq., $100 \mathrm{~mL}$ ). The resulting mixture was extracted with $\mathrm{CH}_{2} \mathrm{Cl}_{2}(3 \times 80 \mathrm{~mL})$, the combined organic phases were dried over anhydrous $\mathrm{Na}_{2} \mathrm{SO}_{4}$ and concentrated under reduced pressure. The residue was purified by flash column chromatography $(0-10 \%$ $\mathrm{MeOH}$ in DCM) to give 3 (950 mg, $3.68 \mathrm{mmol}, 64 \%$ yield). ${ }^{1} \mathrm{H}$ NMR $\left(500 \mathrm{MHz}, \mathrm{DMSO}-\mathrm{d}_{6}\right) \delta 8.81$ (d, $J=5.3 \mathrm{~Hz}, 1 \mathrm{H}), 8.78(\mathrm{~s}, 1 \mathrm{H}), 7.89(\mathrm{~d}, J=5.2 \mathrm{~Hz}, 1 \mathrm{H}), 7.59-7.41(\mathrm{~m}, 4 \mathrm{H}), 4.47(\mathrm{t}, J=5.1 \mathrm{~Hz}, 1 \mathrm{H}), 3.39$ $(\mathrm{td}, J=6.4,5.0 \mathrm{~Hz}, 2 \mathrm{H}), 2.65-2.59(\mathrm{~m}, 2 \mathrm{H}), 1.73-1.65(\mathrm{~m}, 2 \mathrm{H}) .{ }^{13} \mathrm{C}$ NMR $(126 \mathrm{MHz}, \mathrm{DMSO}) \delta 153.05$, $151.11,143.80,131.99,131.96,131.91,130.68,129.45,129.40,129.28,129.21,129.12,129.10$, $128.71,128.57,117.09,60.54,34.48,31.83,31.80$. MS (ESI) $\mathrm{m} / \mathrm{z} 259(\mathrm{M}+\mathrm{H})^{+}$. Expected mass from chemical formula $\mathrm{C}_{14} \mathrm{H}_{14} \mathrm{~N}_{2} \mathrm{O}_{3}: 258.3 \mathrm{Da}$.

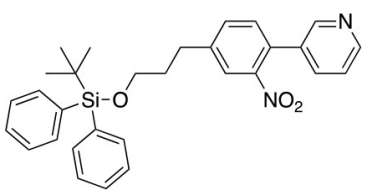

Chemical structure 2. 3-(4-(3-((tert-butyldiphenylsilyl)oxy)propyl)phenyl)-4-nitropyridine (4) DOI: https://doi.org/10.7554/eLife.45457.021

To a stirred solution of $3(950 \mathrm{mg}, 3.68 \mathrm{mmol})$ in $\mathrm{CH}_{2} \mathrm{Cl}_{2}(35 \mathrm{~mL})$ at $25^{\circ} \mathrm{C}$ was added imidazole $(751 \mathrm{mg}, 11.04 \mathrm{mmol})$ and TBDPSCl $(2.01 \mathrm{~g}, 7.36 \mathrm{mmol})$. After stirring at this temperature for $3 \mathrm{hr}$, the reaction was quenched with $\mathrm{NH}_{4} \mathrm{Cl}$ (sat. aq., $100 \mathrm{~mL}$ ). The resulting mixture was extracted with $\mathrm{CH}_{2} \mathrm{Cl}_{2}(2 \times 50 \mathrm{~mL})$, the combined organic phases were washed with brine $(100 \mathrm{~mL})$, dried over anhydrous $\mathrm{Na}_{2} \mathrm{SO}_{4}$ and concentrated under reduced pressure. The residue was purified by flash column chromatography (0-5\% MeOH in DCM) to give 4 (1.62 g, $3.26 \mathrm{mmol}, 89 \%$ yield). ${ }^{1} \mathrm{H}$ NMR (500 $\left.\mathrm{MHz}, \mathrm{DMSO}-\mathrm{d}_{6}\right) \delta 8.90(\mathrm{~d}, J=5.3 \mathrm{~Hz}, 1 \mathrm{H}), 8.85(\mathrm{~s}, 1 \mathrm{H}), 7.99(\mathrm{~d}, J=5.2 \mathrm{~Hz}, 1 \mathrm{H}), 7.66-7.61(\mathrm{~m}, 4 \mathrm{H})$, 7.50-7.41 (m, 6H), 7.35-7.29 (m, 4H), $3.69(\mathrm{t}, J=6.2 \mathrm{~Hz}, 2 \mathrm{H}), 2.74(\mathrm{dd}, J=8.6,6.7 \mathrm{~Hz}, 2 \mathrm{H}), 1.92-$ $1.83(\mathrm{~m}, 2 \mathrm{H}), 1.02(\mathrm{~s}, 9 \mathrm{H}) .{ }^{13} \mathrm{C} \mathrm{NMR}(126 \mathrm{MHz}, \mathrm{DMSO}) \delta 154.54,153.05,151.19,143.25,136.83$, 135.49, 133.71, 130.80, 130.27, 129.63, 129.43, 128.63, 128.35, 117.14, 63.14, 33.88, 31.48, 27.02, 19.15. MS (ESI) $\mathrm{m} / \mathrm{z} 497(\mathrm{M}+\mathrm{H})^{+}$. Expected mass from chemical formula $\mathrm{C} 30 \mathrm{H} 32 \mathrm{~N} 2 \mathrm{O} 3 \mathrm{Si}: 496.68$ Da.

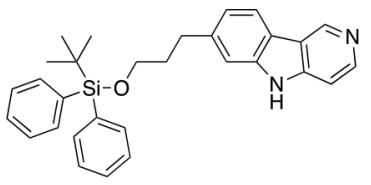

Chemical structure 3. 7-(3-((tert-butyldiphenylsilyl)oxy)propyl)-5H-pyrido[4,3-b]indole (5) DOI: https://doi.org/10.7554/eLife.45457.022

A solution of $4(1.62 \mathrm{~g}, 3.26 \mathrm{mmol})$ in $\mathrm{P}(\mathrm{OEt})_{3}(20 \mathrm{~mL})$ was stirred at $110^{\circ} \mathrm{C}$ for $3 \mathrm{hr}$ before it was concentrated under reduced pressure. The residue was purified by flash column chromatography (0$10 \% \mathrm{MeOH}$ in DCM) to give $\mathbf{5}\left(1.32 \mathrm{~g}, 2.84 \mathrm{mmol}, 87 \%\right.$ yield). ${ }^{1} \mathrm{H}$ NMR $\left(500 \mathrm{MHz}, \mathrm{DMSO}-d_{6}\right) \delta 11.65$ $(\mathrm{s}, 1 \mathrm{H}), 9.30(\mathrm{~s}, 1 \mathrm{H}), 8.41(\mathrm{dd}, J=5.7,1.7 \mathrm{~Hz}, 1 \mathrm{H}), 8.09(\mathrm{~d}, J=7.9 \mathrm{~Hz}, 1 \mathrm{H}), 7.63-7.60(\mathrm{~m}, 4 \mathrm{H}), 7.48-$ $7.36(\mathrm{~m}, 8 \mathrm{H}), 7.08(\mathrm{dt}, J=8.0,1.5 \mathrm{~Hz}, 1 \mathrm{H}), 3.68(\mathrm{t}, J=6.2 \mathrm{~Hz}, 2 \mathrm{H}), 2.85(\mathrm{t}, J=7.6 \mathrm{~Hz}, 2 \mathrm{H}), 1.96-1.88$ $(\mathrm{m}, 2 \mathrm{H}), 1.02(\mathrm{~s}, 9 \mathrm{H}) .{ }^{13} \mathrm{C}$ NMR $(126 \mathrm{MHz}, \mathrm{DMSO}) \delta 144.35,144.16,142.58,141.14,140.49,135.47$, 133.74, 130.22, 128.29, 121.33, 120.85, 119.95, 119.21, 111.35, 106.78, 63.11, 34.57, 32.36, 27.16, 19.27. MS (ESI) $\mathrm{m} / \mathrm{z} 465(\mathrm{M}+\mathrm{H})^{+}$. Expected mass from chemical formula $\mathrm{C} 30 \mathrm{H} 32 \mathrm{~N} 2 \mathrm{O} 3 \mathrm{Si}: 464.23$ Da. 


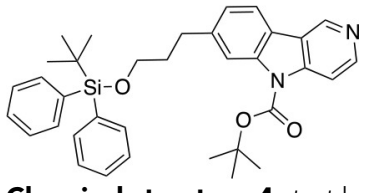

Chemical structure 4. tert-butyl 7-(3-((tert-butyldiphenylsilyl)oxy)propyl)-5H-pyrido[4,3-b]indole-5-carboxylate (6) DOI: https://doi.org/10.7554/eLife.45457.023

To a stirred solution of $5(1.32 \mathrm{~g}, 2.84 \mathrm{mmol})$ and DMAP $(213 \mathrm{mg}, 1.75 \mathrm{mmol})$ in $\mathrm{CH}_{2} \mathrm{Cl}_{2}(30 \mathrm{~mL})$ at $25^{\circ} \mathrm{C}$ was added $\mathrm{Et}_{3} \mathrm{~N}(1.06 \mathrm{~g}, 10.47 \mathrm{mmol})$ and $(\mathrm{Boc})_{2} \mathrm{O}(1.52 \mathrm{~g}, 6.98 \mathrm{mmol})$. After stirring at this temperature for $2 \mathrm{hr}$, the reaction was quenched with $\mathrm{NH}_{4} \mathrm{Cl}$ (sat. aq., $100 \mathrm{~mL}$ ). The resulting mixture was extracted with $\mathrm{CH}_{2} \mathrm{Cl}_{2}(2 \times 50 \mathrm{~mL})$, the combined organic phases were washed with brine (100 $\mathrm{mL}$ ), dried over anhydrous $\mathrm{Na}_{2} \mathrm{SO}_{4}$ and concentrated under reduced pressure. The residue was purified by flash column chromatography to give 6 (1.42 g, $2.52 \mathrm{mmol}, 89 \%$ yield). ${ }^{1} \mathrm{H} \mathrm{NMR}(500 \mathrm{MHz}$, DMSO-d $)_{6} \delta .35(d, J=0.9 \mathrm{~Hz}, 1 \mathrm{H}), 8.58(\mathrm{~d}, J=5.7 \mathrm{~Hz}, 1 \mathrm{H}), 8.12(\mathrm{~d}, J=7.9 \mathrm{~Hz}, 1 \mathrm{H}), 8.09(\mathrm{~d}$, $J=1.3 \mathrm{~Hz}, 1 \mathrm{H}), 8.05(\mathrm{dd}, J=5.7,0.9 \mathrm{~Hz}, 1 \mathrm{H}), 7.61-7.57(\mathrm{~m}, 4 \mathrm{H}), 7.43-7.34(\mathrm{~m}, 6 \mathrm{H}), 7.25$ (dd, $J=7.9,1.5 \mathrm{~Hz}, 1 \mathrm{H}), 3.67(\mathrm{t}, J=6.1 \mathrm{~Hz}, 2 \mathrm{H}), 2.86(\mathrm{t}, J=7.5 \mathrm{~Hz}, 2 \mathrm{H}), 1.91(\mathrm{dq}, J=8.5,6.3 \mathrm{~Hz}, 2 \mathrm{H})$, 1.68 (s, 9H), 0.99 (s, 9H). ${ }^{13} \mathrm{C}$ NMR (126 MHz, DMSO) $\delta 150.29,147.22,142.96,142.68,138.42$, $135.43,133.66,130.18,128.24,128.21,124.88,121.77,121.40,120.77,115.99,110.99,85.39$, $62.99,34.32,32.60,28.14,28.13,27.10,19.22$. MS (ESI) $\mathrm{m} / \mathrm{z} 565(\mathrm{M}+\mathrm{H})^{+}$. Expected mass from chemical formula C35H40N2O3Si: 564.28 Da.

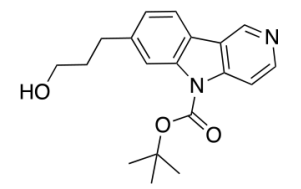

Chemical structure 5. tert-butyl 7-(3-hydroxypropyl)-5H-pyrido[4,3-b]indole-5-carboxylate (7) DOI: https://doi.org/10.7554/eLife.45457.024

To a stirred solution of $6(1.42 \mathrm{~g}, 2.52 \mathrm{mmol})$ in THF $(25 \mathrm{~mL})$ at $0^{\circ} \mathrm{C}$ was added TBAF $(1.0 \mathrm{M}$ in THF, $3.8 \mathrm{~mL}, 3.8 \mathrm{mmol}$ ) dropwise. After stirring at this temperature for $2 \mathrm{hr}$, the reaction was quenched with acetic acid $(0.2 \mathrm{~mL})$. The mixture was concentrated under reduced pressure. The residue was purified by flash column chromatography (0-20\% MeOH in DCM) to give 7 (670 mg, 2.05 mmol, 81\% yield). ${ }^{1} \mathrm{H}$ NMR $\left(500 \mathrm{MHz}, \mathrm{DMSO}-\mathrm{d}_{6}\right) \delta 9.35(\mathrm{~s}, 1 \mathrm{H}), 8.58(\mathrm{~d}, J=5.7 \mathrm{~Hz}, 1 \mathrm{H}), 8.14(\mathrm{~d}$, $J=7.9 \mathrm{~Hz}, 1 \mathrm{H}), 8.12(\mathrm{~s}, 1 \mathrm{H}), 8.04(\mathrm{~d}, J=5.7 \mathrm{~Hz}, 1 \mathrm{H}), 7.30(\mathrm{dd}, J=7.9,1.3 \mathrm{~Hz}, 1 \mathrm{H}), 3.47(\mathrm{t}, J=6.4$ $\mathrm{Hz}, 2 \mathrm{H}), 2.81(\mathrm{dd}, J=8.8,6.7 \mathrm{~Hz}, 2 \mathrm{H}), 1.86-1.77(\mathrm{~m}, 2 \mathrm{H}), 1.72(\mathrm{~s}, 9 \mathrm{H}) .{ }^{13} \mathrm{C}$ NMR $(126 \mathrm{MHz}, \mathrm{DMSO}) \delta$ 149.89, 146.72, 142.85, 142.48, 138.03, 124.53, 121.33, 120.84, 120.29, 115.42, 110.57, 85.02, 60.04, 39.52, 34.51, 32.40, 27.73, 21.06. MS (ESI) $\mathrm{m} / \mathrm{z} 327(\mathrm{M}+\mathrm{H})^{+}$. Expected mass from chemical formula C19H22N2O3: 326.16 Da.<smiles>O=C(O)CCc1ccc2c(c1)[nH]c1ccncc12</smiles>

Chemical structure 6. 3-(5H-pyrido[4,3-b]indol-7-yl)propanoic acid (10) DOI: https://doi.org/10.7554/eLife.45457.025

To a stirred solution of DMSO $(1.30 \mathrm{~g}, 16.6 \mathrm{mmol})$ in $\mathrm{CH}_{2} \mathrm{Cl}_{2}(7 \mathrm{~mL})$ at $-78^{\circ} \mathrm{C}$ was added oxalyl chloride $(783 \mathrm{mg}, 6.16 \mathrm{mmol})$ in $\mathrm{CH}_{2} \mathrm{Cl}_{2}(6 \mathrm{~mL})$ dropwise. After stirring at this temperature for $0.5 \mathrm{hr}$, a solution of $7(670 \mathrm{mg}, 2.05 \mathrm{mmol})$ in $\mathrm{CH}_{2} \mathrm{Cl}_{2}(6 \mathrm{~mL})$ was added dropwise. The mixture was stirred at this temperature for $2 \mathrm{hr}$ followed by the addition of $\mathrm{Et}_{3} \mathrm{~N}(1.035 \mathrm{~g}, 10.25 \mathrm{mmol}$ ) dropwise. The reaction mixture was slowly warmed to $0^{\circ} \mathrm{C}$ over $1 \mathrm{hr}$ and was quenched with $\mathrm{NH}_{4} \mathrm{Cl}$ (sat. aq., 30 $\mathrm{mL})$. The resulting mixture was extracted with $\mathrm{CH}_{2} \mathrm{Cl}_{2}(2 \times 30 \mathrm{~mL})$, the combined organic phases were washed with brine $(100 \mathrm{~mL})$, dried over anhydrous $\mathrm{Na}_{2} \mathrm{SO}_{4}$ and concentrated under reduced pressure. The residue was used in the next step without further purification.

To a stirred solution of the above residue in THF $(10 \mathrm{~mL}), t-\mathrm{BuOH}(5 \mathrm{~mL})$ and $\mathrm{H}_{2} \mathrm{O}(5 \mathrm{~mL})$ at $25^{\circ} \mathrm{C}$ was added $\mathrm{NaH}_{2} \mathrm{PO}_{4} \bullet \mathrm{H}_{2} \mathrm{O}(2.55 \mathrm{~g}, 18.5 \mathrm{mmol}), 2$-methyl-butene $(5 \mathrm{~mL})$ and sodium chlorite $(1.64 \mathrm{~g}$, $18.5 \mathrm{mmol})$. After stirring at this temperature for $2 \mathrm{hr}$, the reaction was diluted with $\mathrm{H}_{2} \mathrm{O}(50 \mathrm{~mL})$. The resulting mixture was extracted with $\mathrm{CH}_{2} \mathrm{Cl}_{2}(2 \times 50 \mathrm{~mL})$, the combined organic phases were 
dried over anhydrous $\mathrm{Na}_{2} \mathrm{SO}_{4}$ and concentrated under reduced pressure. The residue was used in the next step without further purification.

A solution of the above mixture in $\mathrm{CH}_{2} \mathrm{Cl}_{2}(12 \mathrm{~mL})$ and TFA $(6 \mathrm{~mL})$ was stirred at $25^{\circ} \mathrm{C}$ for $12 \mathrm{hr}$ before it was concentrated under reduced pressure. The residue was dissolved in $\mathrm{NaOH}(0.5 \mathrm{M}$, aq., $20 \mathrm{~mL}$ ) and was extracted with $\mathrm{CH}_{2} \mathrm{Cl}_{2}(4 \times 15 \mathrm{~mL})$. The water phase was added $\mathrm{HCl}$ (aq.,1.0 M) dropwise to adjust the $\mathrm{pH}$ to $6-7$. The resulting mixture was extracted with $\mathrm{CHCl}_{3} /{ }^{i} \operatorname{PrOH}(4 / 1$, $3 \times 30 \mathrm{~mL}$ ), the combined organic phases were dried over anhydrous $\mathrm{Na}_{2} \mathrm{SO}_{4}$ and concentrated under reduced pressure to afford $10(357 \mathrm{mg}, 1.48 \mathrm{mmol}, 73 \%$ yield over three steps) as a pure compound. ${ }^{1} \mathrm{H}$ NMR $\left(500 \mathrm{MHz}\right.$, Methanol- $\left.d_{4}\right) \delta 9.22(\mathrm{~s}, 1 \mathrm{H}), 8.37(\mathrm{~s}, 1 \mathrm{H}), 8.10(\mathrm{~d}, \mathrm{~J}=8.0 \mathrm{~Hz}, 1 \mathrm{H})$, $7.58(\mathrm{~d}, J=6.0 \mathrm{~Hz}, 1 \mathrm{H}), 7.48(\mathrm{~s}, 1 \mathrm{H}), 7.27(\mathrm{dd}, J=8.1,1.4 \mathrm{~Hz}, 1 \mathrm{H}), 3.12(\mathrm{t}, J=7.7 \mathrm{~Hz}, 2 \mathrm{H}), 2.63(\mathrm{t}$, $J=7.8 \mathrm{~Hz}, 2 \mathrm{H}) .{ }^{13} \mathrm{C}$ NMR $(126 \mathrm{MHz}, \mathrm{MeOD}) \delta 172.25,142.51,139.68,138.42,122.01,120.84$, 120.39, 118.91, 110.98, 106.62, 32.19, 29.36. MS (ESI) $\mathrm{m} / \mathrm{z} 241(\mathrm{M}+\mathrm{H})^{+}$. Expected mass from chemical formula C14H12N2O2: $240.09 \mathrm{Da}$.

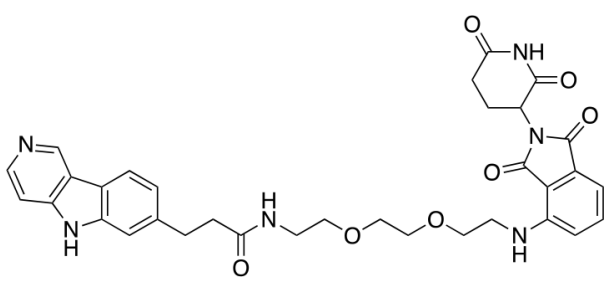

Chemical structure 7. QC-01-175

DOI: https://doi.org/10.7554/eLife.45457.026

To a stirred solution of carboxylic acid $10(6.8 \mathrm{mg}, 0.02 \mathrm{mmol}), \mathrm{EDCl}(11.5 \mathrm{mg}, 0.06 \mathrm{mmol})$, DMAP $(2.2 \mathrm{mg}, 0.02 \mathrm{mmol})$ and DIPEA $(14.3 \mathrm{mg}, 0.12 \mathrm{mmol})$ in $\mathrm{CH}_{2} \mathrm{Cl}_{2}(0.6 \mathrm{~mL})$ at $25^{\circ} \mathrm{C}$ was added the corresponding primary amine $(12.1 \mathrm{mg}, 0.03 \mathrm{mmol})$. The resulting reaction mixture was stirred at this temperature for $4 \mathrm{hr}$, and then concentrated under reduced pressure. The residue was purified by Reverse-Phase HPLC to give QC-01-175 (9.7 mg, $0.0134 \mathrm{mmol}, 67 \%$ yield). ${ }^{1} \mathrm{H}$ NMR (500 MHz, Methanol- $\left.d_{4}\right) \delta 9.44(\mathrm{~s}, 1 \mathrm{H}), 8.47(\mathrm{~d}, J=6.7 \mathrm{~Hz}, 1 \mathrm{H}), 8.21(\mathrm{~d}, J=8.1 \mathrm{~Hz}, 1 \mathrm{H}), 7.88(\mathrm{~d}, J=6.7 \mathrm{~Hz}, 1 \mathrm{H})$, $7.56(\mathrm{~s}, 1 \mathrm{H}), 7.43(\mathrm{dd}, J=8.5,7.1 \mathrm{~Hz}, 1 \mathrm{H}), 7.36(\mathrm{dd}, J=8.1,1.3 \mathrm{~Hz}, 1 \mathrm{H}), 6.96(\mathrm{~d}, J=8.5 \mathrm{~Hz}, 1 \mathrm{H})$, $6.91(\mathrm{~d}, J=7.0 \mathrm{~Hz}, 1 \mathrm{H}), 5.02(\mathrm{dd}, J=12.8,5.5 \mathrm{~Hz}, 1 \mathrm{H}), 3.76-3.69(\mathrm{~m}, 2 \mathrm{H}), 3.67-3.64(\mathrm{~m}, 6 \mathrm{H}), 3.60$ $3.55(\mathrm{~m}, 3 \mathrm{H}), 3.53$ (dd, J=6.0, 3.2 Hz, 2H), 3.47 (t, J=5.4 Hz, 2H), 3.40 (t, J = 5.2 Hz, 2H), 3.13 (t, $J=7.5 \mathrm{~Hz}, 2 \mathrm{H}), 2.58(\mathrm{t}, J=7.5 \mathrm{~Hz}, 2 \mathrm{H}) .{ }^{13} \mathrm{C}$ NMR (126 MHz, MeOD) $\delta$ 146.59, 143.73, 135.71, 134.14, 133.82, 123.70, 121.45, 116.71, 112.08, 110.53, 107.77, 99.98, 70.14, 69.83, 69.17, 69.13, 48.77, 41.79, 39.02, 31.95, 30.77, 22.41. MS (ESI) $\mathrm{m} / \mathrm{z} 627(\mathrm{M}+\mathrm{H})^{+}$. Expected mass from chemical formula $\mathrm{C}_{33} \mathrm{H}_{34} \mathrm{~N}_{6} \mathrm{O}_{7}: 626.25 \mathrm{Da}$.

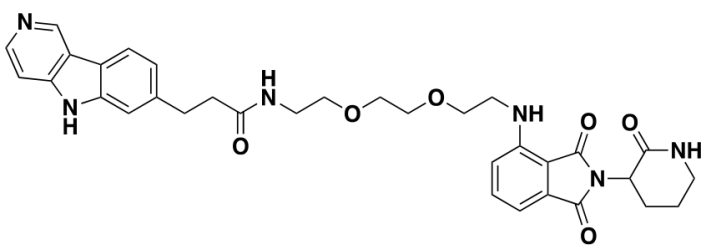

Chemical structure 8. QC-03-075: Was prepared according to Scheme 1.

DOI: https://doi.org/10.7554/eLife.45457.027

${ }^{1} \mathrm{H}$ NMR (500 MHz, DMSO-d $) \delta 13.01(\mathrm{~s}, 1 \mathrm{H}), 9.66(\mathrm{~s}, 1 \mathrm{H}), 8.61(\mathrm{~d}, J=6.7 \mathrm{~Hz}, 1 \mathrm{H}), 8.31(\mathrm{~d}$, $J=8.1 \mathrm{~Hz}, 1 \mathrm{H}), 7.95(\mathrm{~d}, J=6.6 \mathrm{~Hz}, 1 \mathrm{H}), 7.90(\mathrm{t}, J=5.7 \mathrm{~Hz}, 1 \mathrm{H}), 7.82(\mathrm{~d}, J=2.9 \mathrm{~Hz}, 1 \mathrm{H}), 7.58(\mathrm{~s}, 1 \mathrm{H})$, 7.56-7.49 (m, 1H), $7.34(\mathrm{~d}, J=8.1 \mathrm{~Hz}, 1 \mathrm{H}), 7.07(\mathrm{~d}, J=8.6 \mathrm{~Hz}, 1 \mathrm{H}), 6.97(\mathrm{~d}, J=7.0 \mathrm{~Hz}, 1 \mathrm{H}), 6.54(\mathrm{t}$, $J=5.8 \mathrm{~Hz}, 1 \mathrm{H}), 4.50(\mathrm{dd}, J=11.9,6.4 \mathrm{~Hz}, 1 \mathrm{H}), 3.57(\mathrm{t}, J=5.5 \mathrm{~Hz}, 2 \mathrm{H}), 3.51(\mathrm{dd}, J=6.0,3.4 \mathrm{~Hz}, 2 \mathrm{H})$, $3.46(t, J=3.5 \mathrm{~Hz}, 2 \mathrm{H}), 3.42(\mathrm{~d}, J=5.8 \mathrm{~Hz}, 1 \mathrm{H}), 3.19(\mathrm{q}, J=5.4 \mathrm{~Hz}, 4 \mathrm{H}), 3.03(\mathrm{t}, J=7.6 \mathrm{~Hz}, 2 \mathrm{H}), 2.47$ $(\mathrm{d}, J=7.7 \mathrm{~Hz}, 4 \mathrm{H}), 2.19$ (qd, $J=12.3,4.4 \mathrm{~Hz}, 1 \mathrm{H}), 2.01-1.78(\mathrm{~m}, 3 \mathrm{H}) .{ }^{13} \mathrm{C}$ NMR $(126 \mathrm{MHz}, \mathrm{DMSO}) \delta$ 146.95, 135.34, 123.75, 122.31, 117.58, 112.67, 110.90, 108.62, 84.75, 76.26, 70.11, 69.66, 69.32, 49.04, 49.04, 42.14, 41.87, 37.53, 32.07, 26.33, 22.19. MS (ESI) $\mathrm{m} / \mathrm{z} 613(\mathrm{M}+\mathrm{H})^{+}$. Expected mass from chemical formula $\mathrm{C}_{33} \mathrm{H}_{36} \mathrm{~N}_{6} \mathrm{O}_{6}: 612.27 \mathrm{Da}$. 


\section{Bio-layer interferometry (BLI) biosensor assay}

BLI was performed in the Octet Red384 instrument (ForteBio, Fremont CA, USA) with 1X PBS and $0.01 \%$ Brij-35 as the assay buffer. Recombinant human tau proteins (Tau-441(WT), Tau-441(A152T) and Tau-441(P301L), 2N4R isoform) were purchased from SignalChem (Richmond, British Columbia). Tau-441(WT), Tau-441(A152T) and Tau-441(P301L) were labeled with biotin using the EZ-LinkNHSPEG4-Biotinylation Kit (Thermo Scientific, Waltham, MA), and excess biotin reagent was removed using a spin desalting column as per manufacturer's instruction. The biotinylated protein samples for BLI were purified in $1 \mathrm{X}$ phosphate buffered saline (PBS). Streptavidin (SA) sensors were used to measure the biophysical interaction between the small molecules and biotinylated tau. Prior to the initiation of BLI, the SA sensors were soaked by dipping in $200 \mu \mathrm{L}$ of assay buffer in a 96-well Greiner Bio-One Black flat bottom plate (Greiner, Monroe NC, USA Cat.655209). The assay was performed in $80 \mu \mathrm{L}$ volume in Greiner Bio-One 384-well black flat bottom PP plates (Greiner, Cat.781209) with an initial baseline step, followed by loading of $250 \mathrm{nM}$ biotinylated tau protein. The small molecules samples and recombinant proteins were arranged in the 384-well plate according to a plate map recommended for the eight-channel mode kinetic analysis, where the sensors move from low to high concentration of small molecule samples. Subsequent steps included a second baseline (120 s), followed by association ( $240 \mathrm{~s}$ ) and dissociation ( $240 \mathrm{~s}$ ) cycles. All the sensors were loaded with biotinylated tau protein, and two sensors were loaded with appropriate concentration of DMSO (comparable to small molecule samples) in assay buffer to be used as reference. Data analysis was performed using Data Acquisition HT 11.0 software following reference subtraction (an average of two sensors with DMSO) using a 1:1 binding model and an individual fit of each replicate. The equilibrium dissociation constant $\left(K_{D}\right)$ was estimated using data at equilibrium from each available small molecule concentration with steady-state analysis. The instrument manufacturer (Fortebio, article \#137) recommends the steady state option for analyzing interactions that are either low affinity or very fast on-and-off affinity rates. For steady-state analysis of ' $R$ equilibrium' $\left(R_{\text {eq }}\right)$ was fitted according to $1: 1$ binding model with the equation Response $=\left(R_{\max } \times\right.$ Conc. $) /\left(K_{D}+\right.$ Conc. $)$. When $R_{\text {eq }}$ option is selected, Fortebio's software calculates affinity constants based on the $R_{\text {eq }}$ values determined from the curve fits. In the steady-state analysis, $R_{\text {eq }}$ is plotted against the small molecule concentration to infer the $R_{\max } . K_{D}$ is estimated as the concentration where $50 \%$ of $R_{\max }$ is achieved. As per the instrument manufacturer's instructions, if all curves have reached equilibrium, these two sets of values correspond to 'Response,' and $R_{\text {eq }}$ values should match. For T807 and QC-01-175, the values of 'Response' and $R_{\text {eq }}$ match as evidenced by the raw data as well as a value of $R_{\max } / R_{\text {eq }}(\%)$ close to 1.

\section{Monoamine oxidase assay}

The Monoamine oxidase (MAO) activity measurements were performed using a MAO-Glo assay kit (Promega, Madison, WI), in a 384-well plate (Proxiplate 384 Plus, Perkin Elmer, Waltham, MA) with the miniaturization of final assay volume to $20 \mu \mathrm{L}$, as per the manufacturer's instructions. In brief, MAO reactions were terminated after a 60-min enzymatic reaction, by the addition of reconstituted Luciferin Detection Reagent. Following a 20-min incubation with the detection reagent, the luminescence was measured using a multi-label plate reader (Envision, Perkin Elmer). $I_{50}$ values were estimated by fitting percentage inhibition vs. compound concentration in a variable slope (four parameter) fit.

\section{Human neuronal cell culture and compound treatment}

Cells from individuals carrying the tau risk variant $\mathrm{A} 152 \mathrm{~T}$ (c.1407G $>\mathrm{A} ; \mathrm{NCBI}$ RefSeq NM_001123066, rs143624519), the autosomal dominant mutation P301L (c.C1907T; NCBI NM_001123066, rs63751273), or age-matched non-mutant WT tau were employed in this study (Figure 2-source data 1). Dermal fibroblasts from the tau-P301L carrier and the healthy individual were generated from a skin biopsy from subjects within the MGH Frontotemporal Disorders Unit as part of the MGH Neurodegeneration Repository. Approval for human subjects' work was obtained under a Partners/MGH-approved IRB Protocol (\#2010P001611/MGH). Fibroblasts were reprogrammed into iPSCs, which were subsequently converted into cortical-enriched neural progenitor cells (NPCs) and differentiated into neuronal cells as previously described (Almeida et al., 2012; Seo et alı, 2017; Silva et alı, 2016; Sheridan et al., 2011) (Silva MC, Manuscript in preparation, 
2019). Briefly, cells were cultured in 6-well (Fisher Scientific Corning, Pittsburgh, PA) or 96-well (Fisher Scientific Corning) plates coated with poly-ornithine $(20 \mu \mathrm{g} / \mathrm{mL}$ in water, Sigma, St. Louis, $\mathrm{MO}$ ) and laminin (5 $\mathrm{gg} / \mathrm{mL}$ in PBS, Sigma) (POL-coated), in DMEM/F12-B27 media [70\% DMEM (Gibco, Carlsbad, CA), 30\% Ham's-F12 (Fisher Scientific Corning), 2\% B27 (Gibco), 1\% penicillinstreptomycin (Gibco)]. Media was supplemented with EGF ( $20 \mathrm{ng} / \mathrm{mL}$, Sigma), FGF ( $20 \mathrm{ng} / \mathrm{mL}$, Stemgent, Cambridge, MA) and heparin ( $5 \mu \mathrm{g} / \mathrm{mL}$, Sigma), to promote NPC proliferation and expansion. The growth factors were withdrawn to promote neural differentiation for 6 to 8 weeks, with half media change two times per week. Cell lines' identity was authenticated by SANGER sequencing, karyotyping and ACGH analysis at different stages of culture maintenance from iPSC to NPC. All working cell lines tested negative for mycoplasma contamination.

Compound treatment in six-well plates was performed in $2 \mathrm{~mL}$ media volume by removing $1 \mathrm{~mL}$ of conditioned media from the culture and adding $1 \mathrm{~mL}$ of new media pre-mixed with the compound at the appropriate $2 \mathrm{X}$ concentration, followed by incubation at $37^{\circ} \mathrm{C}$ for the designated period of time. Compound treatment in 96-well plates was performed in $100 \mu \mathrm{L}$ media volume by adding compound directly to each well, followed by incubation at $37^{\circ} \mathrm{C}$. When testing the effect of drug pretreatment, the first compound was added as described above for the period of time needed, and then QC-01-175 was added directly onto the media without media exchange.

\section{Antibodies and respective commercial information}

Total tau TAU5 for western blotting (Invitrogen, Rockford, IL), total tau TAU5 for IP (AbCam, Cambridge, MA), total tau K9JA for IF (Dako/Agilent, Santa Clara, CA), P-tau Ser396 (Invitrogen), P-tau PHF-1 (kindly provided by Dr. Peter Davies, Albert Einstein College of Medicine, NY). Neuronal marker MAP2 (Chemicon/Millipore). CRL4 ${ }^{\text {CRBN }}$ E3 Ligase components DDB1 (AbCam), CUL4A (Cell Signaling Technology), and CRBN (ProteinTech, Rosemont, IL). Anti-Ubiquitin, clone Ubi-1 (Millipore, Darmstadt, Germany). Internal controls GAPDH (Abcam) and $\beta$-Actin (Sigma). Nuclear stain Hoechst 33342 (Invitrogen).

\section{Cell lysis and western blotting analysis}

Neurons differentiated in six-well plates for 6 weeks were washed and collected in PBS, lysed in RIPA buffer (Boston Bio-Products, Boston, MA) supplemented with 2\% SDS (Sigma), protease inhibitors cocktail (Roche Complete Mini tablets, Mannheim, Germany), and phosphatase inhibitors cocktail (Sigma), followed by water sonication (Bransonic Ultrasonic Baths, Thomas Scientific, Danbury, CT) and 20,000 g centrifugation for $20 \mathrm{~min}$. Supernatants were transferred to new tubes and total protein concentration was quantified with the Pierce BCA Protein Assay Kit (ThermoFisher Scientific, Carlsbad, CA). Human recombinant tau protein ladder was purchased from Sigma. Electrophoresis were performed with the Novex NuPAGE SDS-PAGE Gel System (Invitrogen, Carlsbad, CA), by running $10 \mu \mathrm{g}$ of total protein (pre-boiled in SDS-DTT loading buffer, NEB, Ipswich, MA) on pre-cast SDS-PAGE. Gels were transferred onto PVDF membranes (EMD Millipore) using standard procedures. Membranes were blocked in 5\% BSA (Sigma) in Tris-buffered saline with Tween-20 (TBST/Biorad, Hercules, CA) for $2 \mathrm{hr}$, incubated overnight with primary antibody (see antibody section) at $4^{\circ} \mathrm{C}$, followed by corresponding HRP-linked secondary antibody incubation (Cell Signaling Technology, Danvers, MA). Blots were developed with SuperSignal West Pico Chemiluminescent Substrate (ThermoFisher) according to manufacturer's instructions and exposed to autoradiographic films (LabScientific by ThermoFischer) that, in turn, were scanned on an Epson Perfection V800 Photo Scanner. Protein bands densitometry (pixel mean intensity) was measured with the Adobe Photoshop CS5 Histogram function and normalized to the respective internal control ( $\beta$-Actin or GAPDH) band.

\section{Human tau ELISA}

Neuronal cells differentiated in six-well plate format for 6 weeks, were collected as described for western blotting, and lysed in ELISA-compatible buffer (Invitrogen FNN0011), supplemented with 1 mM PMSF, protease (Roche) and phosphatase (Sigma) inhibitors cocktails, for $30 \mathrm{~min}$ on ice with quick vortexing. Lysates were clarified by centrifugation at $13,000 \mathrm{rpm}$ at $4^{\circ} \mathrm{C}$ for $10 \mathrm{~min}$. The clear lysates were then transferred to new microfuge tubes and total protein concentration was quantified with the Pierce BCA Protein Assay Kit (ThermoFisher Scientific). ELISA assays were performed according to manufacturer instructions: Human Total Tau ELISA (Invitrogen Kit KHB0041/KHB0042) 
and P-Tau[pS396] Human ELISA Kit (Invitrogen Kit KHB7031). Data was plotted using GraphPad Prism version 8.0.

\section{Immunofluorescence assay}

A152T NPCs were plated and differentiated in 96-well black clear-bottom plates (Corning) POLcoated for 6 weeks. Neurons were fixed with $4 \%(\mathrm{v} / \mathrm{v})$ formaldehyde-PBS (Tousimis, Rockville, MD) for $20 \mathrm{~min}$, washed in PBS (Corning), incubated in blocking/permeabilization buffer [10 mg/mL BSA (Sigma), 0.05\% (v/v) Tween-20 (Biorad), 2\% (v/v) goat serum, 0.1\% Triton X-100 (Biorad), 92\% (v/v) PBS] for $2 \mathrm{hr}$, followed by overnight incubation with primary antibodies (see antibody section), PBS washed, and then incubated with the corresponding AlexaFluor conjugated secondary antibodies (Life Technologies, Carlsbad, CA). Image acquisition was done with the IN Cell Analyzer 6000 Cell Imaging System (GE Healthcare Life Sciences, Marlborough, MA).

\section{Co-immunoprecipitation assays}

NPCs were plated and differentiated for 6 weeks, as described above, in six-well POL-coated plates. For each pull-down experiment, three wells of treated neurons were PBS-washed and combined into a single pellet. To stabilize and detect complex formation, all steps were performed on ice or at $4^{\circ} \mathrm{C}$. Co-IP was performed with the Immunoprecipitation Kit Dynabeads Protein G (Novex by Life Technologies/Thermo 10007D), according to manufacturer instructions. Briefly, cell lysis was achieved with ice cold Pierce IP Lysis Buffer (ThermoFisher Scientific) for $15 \mathrm{~min}$ at $4^{\circ} \mathrm{C}$, followed by centrifugation at 10,000 $\mathrm{g}$ for $10 \mathrm{~min}$. The supernatant (Input) was transferred to a new tube and immediately aliquoted for the BCA assay to determine protein concentration. Antibodies, $10 \mu \mathrm{g}$ of TAU5 and 5 $\mu \mathrm{g}$ of DDB1, were bound to Dynabeads $(1.5 \mathrm{mg})$ per each condition to be tested (treatments). Immunoprecipitation of the target antigen (tau or DDB1) was performed by mixing protein lysate (200 $\mu \mathrm{L}$ sample corresponding to $300 \mu \mathrm{g}$ of total protein) to each Dynabeads-antibody complex. All other steps followed the kit's protocol. Elution was accomplished with $20 \mu \mathrm{L}$ Elution Buffer and 10 $\mu \mathrm{L}$ of SDS-sample buffer with DTT (New England Biolabs), followed by removal of the magnetic beads. A volume of $10 \mu \mathrm{L}$ of each IP sample was loaded onto SDS-PAGE for western blotting as described above.

\section{Mass spectrometry global proteomics}

Sample preparation TMT LC-MS3 mass spectrometry

A152T neurons at 6 weeks of differentiation were treated with DMSO vehicle, $1 \mu \mathrm{M}$ of degrader QC-01-175 or $1 \mu \mathrm{M}$ negative control QC-03-075 in biological triplicates for $4 \mathrm{hr}$, or pre-treated for 30 min with $10 \mu \mathrm{M}$ MLN4924 followed by $1 \mu \mathrm{M}$ QC-01-175 addition for $3.5 \mathrm{hr}$, in biological duplicates. Neuronal cells were washed in PBS (Corning VWR, Radnor, PA) and collected at $3000 \mathrm{~g}$ centrifugation. Lysis buffer (8 M Urea, $50 \mathrm{mM} \mathrm{NaCl}, 50 \mathrm{mM}$ 4-(2hydroxyethyl)-1-piperazineethanesulfonic acid (EPPS) $\mathrm{pH} 8.5$, protease and phosphatase inhibitors (Roche) were added to the cell pellets and homogenized by 20 passes through a 21 gauge (1.25 in. long) needle to achieve a cell lysate with a protein concentration between $0.25-2 \mathrm{mg} / \mathrm{mL}$. A micro-BCA assay (Pierce) was used to determine final protein concentration in the cell lysates. $100 \mu \mathrm{g}$ of protein for each sample were reduced and alkylated as previously described (Donovan et al., 2018). Proteins were precipitated using methanol/chloroform. In brief, four volumes of methanol were added to the cell lysate, followed by one volume of chloroform, and finally three volumes of water. The mixture was vortexed and centrifuged to separate the chloroform phase from the aqueous phase. The precipitated protein was washed with three volumes of methanol, centrifuged and the resulting washed precipitated protein was allowed to air dry. Precipitated protein was resuspended in $4 \mathrm{M}$ Urea, $50 \mathrm{mM} \mathrm{HEPES} \mathrm{pH} \mathrm{7.4,} \mathrm{fol-}$ lowed by dilution to $1 \mathrm{M}$ urea with the addition of $200 \mathrm{mM}$ EPPS, $\mathrm{pH}$ 8. Proteins were first digested with LysC (1:50; enzyme:protein; Fisher Scientific) for $12 \mathrm{hr}$ at room temperature. The Lys $\mathrm{C}$ digestion was diluted to $0.5 \mathrm{M}$ Urea with $200 \mathrm{mM}$ EPPS pH eight followed by digestion with trypsin (1:50; enzyme:protein; Promega) for $6 \mathrm{hr}$ at $37^{\circ} \mathrm{C}$. Tandem mass tag (TMT) reagents (Thermo Fisher Scientific) were dissolved in anhydrous acetonitrile (ACN) according to manufacturer's instructions. Anhydrous ACN was added to each peptide sample to a final concentration of $30 \% \mathrm{v} / \mathrm{v}$, and labeling was induced with the addition of TMT reagent to each sample at a ratio of 1:4 peptide:TMT label. The 11-plex labeling reactions were performed for $1.5 \mathrm{hr}$ at room temperature and the reaction 
quenched by the addition of hydroxylamine to a final concentration of $0.3 \%$ for 15 min at room temperature. The sample channels were combined at a 1:1:1:1:1:1:1:1:1:1:1 ratio, desalted using $C_{18}$ solid phase extraction cartridges (Waters, Milford, MA) and analyzed by LC-MS for channel ratio comparison. Samples were then combined using the adjusted volumes determined in the channel ratio analysis and dried down in a speed vacuum. The combined sample was then resuspended in $1 \%$ formic acid and acidified $(\mathrm{pH} \mathrm{2-3)} \mathrm{before} \mathrm{being} \mathrm{subjected} \mathrm{to} \mathrm{desalting} \mathrm{with} \mathrm{C18} \mathrm{SPE} \mathrm{(Sep-Pak,}$ Waters). Samples were then offline fractionated into 96 fractions by high-pH reverse-phase HPLC (Agilent LC1260, Santa Clara, CA) through an aeris peptide xb-c18 column (phenomenex) with mobile phase A containing $5 \%$ acetonitrile and $10 \mathrm{mM} \mathrm{NH}_{4} \mathrm{HCO}_{3}$ in LC-MS grade $\mathrm{H}_{2} \mathrm{O}$, and mobile phase $\mathrm{B}$ containing $90 \%$ acetonitrile and $10 \mathrm{mM} \mathrm{NH}_{4} \mathrm{HCO}_{3}$ in $\mathrm{LC}-\mathrm{MS}$ grade $\mathrm{H}_{2} \mathrm{O}$ (both $\mathrm{pH}$ 8.0). The 96 resulting fractions were then pooled in a non-continuous manner into 24 fractions and these fractions were used for subsequent mass spectrometry analysis.

Data were collected using an Orbitrap Fusion Lumos mass spectrometer (ThermoFisher Scientific, San Jose, CA) coupled with a Proxeon EASY-nLC 1200 LC pump (ThermoFisher Scientific). Peptides were separated on an EasySpray ES803 $75 \mu \mathrm{m}$ inner diameter microcapillary column (ThermoFisher Scientific). Peptides were separated using a 190 min gradient of $6-27 \%$ acetonitrile in $1.0 \%$ formic acid with a flow rate of $350 \mathrm{~nL} / \mathrm{min}$. Each analysis used an MS3-based TMT method as described previously (McAlister et al., 2014). The data were acquired using a mass range of $\mathrm{m} / \mathrm{z} 340-1350$, resolution 120,000, AGC target $5 \times 10^{5}$, maximum injection time $100 \mathrm{~ms}$, dynamic exclusion of $120 \mathrm{~s}$ for the peptide measurements in the Orbitrap. Data dependent MS2 spectra were acquired in the ion trap with a normalized collision energy (NCE) set at 35\%, AGC target set to $1.8 \times 10^{4}$ and a maximum injection time of $120 \mathrm{~ms}$. MS3 scans were acquired in the Orbitrap with HCD collision energy set to $55 \%$, AGC target set to $2 \times 10^{5}$, maximum injection time of $150 \mathrm{~ms}$, resolution at 50,000 and with a maximum synchronous precursor selection (SPS) precursors set to 10. The Advanced Peak Detection (APD) algorithm was disabled.

\section{LC-MS data analysis}

Proteome Discoverer 2.2 (ThermoFisher Scientific) was used for .RAW file processing and controlling peptide and protein level false discovery rates, assembling proteins from peptides, and protein quantification from peptides. MS/MS spectra were searched against a Uniprot human database (September 2016) with both the forward and reverse sequences. Database search criteria are as follows: tryptic with two missed cleavages, a precursor mass tolerance of $20 \mathrm{ppm}$, fragment ion mass tolerance of 0.6 Da, static alkylation of cysteine (57.0211 Da), static TMT labeling of lysine residues and N-termini of peptides (229.163 Da), variable oxidation of methionine (15.9951 Da), variable phosphorylation of serine, threonine and tyrosine $(79.966 \mathrm{Da})$ and variable acetylation (42.011 Da), Methionine-loss (131.040 Da) or methionine-loss + acetylation (83.030 Da) of the protein $\mathrm{N}$-terminus. TMT reporter ion intensities were measured using a $0.003 \mathrm{Da}$ window around the theoretical $\mathrm{m} / \mathrm{z}$ for each reporter ion in the MS3 scan. Peptide spectral matches with poor quality MS3 spectra were excluded from quantitation (summed signal-to-noise across 11 channels $<200$ and precursor isolation specificity $<0.5$ ), and resulting data was filtered to only include proteins that had a minimum of two unique peptides identified. Reporter ion intensities were normalized and scaled using in-house scripts in the R framework (Team RCR: A Language and Environment for Statistical Computing http://www.R-project.org/; accessed Nov. 1, 2017). Statistical analysis was carried out using the limma package within the $\mathrm{R}$ framework (Ritchie et al., 2015).

\section{Neuronal stress and viability assay}

Stress vulnerability assays were performed as previously described (Silva et al., 2016) (Figure 7B). NPCs were plated and differentiated in 96-well plate format, for eight weeks. Either QC-01-175, QC-03-075 or vehicle (DMSO) were added directly into the media (100 $\mu \mathrm{L}$ ) to a final concentration of $5 \mu \mathrm{M}$, and incubated for $8 \mathrm{hr}$ at $37^{\circ} \mathrm{C}$. Then, each well was treated with either $10 \mu \mathrm{M}$ of amyloidbeta(1-42) (Enzo Lifesciences, Farmingdale, NY), or vehicle alone, for an additional 16 hr incubation. At $24 \mathrm{hr}$, viability was measured with the Alamar Blue Cell viability reagent (Life Technologies), according to manufacturer instructions. Readings were done in the EnVision Multilabel Plate Reader (Perkin Elmer, Waltham, MA). 


\section{Data availability}

The compounds QC-01-175-1 and QC-03-075-1 are available from the Gray laboratory upon request. All mass spectrometry raw data is deposited and made available via the PRIDE archive under project accession number PXD012515.

\section{Acknowledgements}

We wish to thank Dr. Kelly L Arnett and Harvard's Center for Macromolecular Interaction for advice regarding Biolayer Interferometry (BLI), and Dr. Peter Davies (Albert Einstein College of Medicine, NY) for kindly sharing the Tau PHF-1 antibody. Members of the Haggarty, Gray, Fischer laboratory along with Dr. Milka Kostic and the Tau Consortium Drug Discovery Group are thanked for helpful feedback on the experimental data and manuscript content.

\section{Additional information}

\section{Competing interests}

M Catarina Silva, Fleur M Ferguson, Quan Cai: is a co-inventor on a patent covering the molecules disclosed in this publication (WO/2019/014429). Bradford C Dickerson: is a consultant for Merck, Lilly, Biogen, and Piramal; and receives royalties from Oxford University Press, Cambridge University Press, and Elsevier. Eric S Fischer: is a SAB member and equity holder in C4 Therapeutics and a consultant to Novartis, AbbVie, and Pfizer. The Fischer lab receives or has received research funding from Novartis, Astellas and Deerfield. Nathanael S Gray: is a founder, science advisory board member (SAB) and equity holder in Gatekeeper, Syros, Petra, C4, B2S and Soltego. The Gray lab receives or has received research funding from Novartis, Takeda, Astellas, Taiho, Jansen, Kinogen, Her2llc, Deerfield and Sanofi. Co-inventor on a patent covering the molecules disclosed in this publication (WO/2019/014429). Stephen J Haggarty: is a member of the SAB and equity holder in Rodin Therapeutics, Psy Therapeutics, and Frequency Therapeutics. His laboratory has received funding from the Tau Consortium, F-Prime Biomedical Research Initiative, AstraZeneca, JW Pharmaceuticals and speaking fees from AstraZeneca, Amgen, Merck. Co-inventor on a patent covering the molecules disclosed in this publication (WO/2019/014429). The other authors declare that no competing interests exist.

Funding

\begin{tabular}{lll} 
Funder & Grant reference number & Author \\
\hline National Institutes of Health & R21NS085487 & M Catarina Silva \\
& & Diane E Lucente \\
Bradford C Dickerson & Stephen J Haggarty \\
& & M Catarina Silva \\
\hline Tau Consortium & Ghata Nandi \\
& Debasis Patnaik \\
& Stephen J Haggarty \\
\hline F-Prime Biomedical Research & M Catarina Silva \\
Initiative & Fleur M Ferguson \\
& Ghata Nandi \\
& Debasis Patnaik \\
& Nathanael S Gray \\
\hline National Institutes of Health & R01CA214608 & Stephen J Haggarty \\
\hline National Institutes of Health & R01CA218278 & Katherine A Donovan \\
& & Eric S Fischer \\
\hline & Katherine A Donovan \\
& & Eric S Fischer \\
\hline
\end{tabular}


The funders had no role in study design, data collection and interpretation, or the decision to submit the work for publication. Eric S Fischer is a Damon RunyonRachleff Innovator supported in part by the Damon Runyon Cancer Research Foundation (DRR-50-18).

Author contributions

M Catarina Silva, Fleur M Ferguson, Katherine A Donovan, Conceptualization, Resources, Formal analysis, Investigation, Methodology, Writing-original draft, Writing-review and editing; Quan Cai, Conceptualization, Resources, Investigation, Methodology; Ghata Nandi, Debasis Patnaik, Resources, Formal analysis, Investigation; Tinghu Zhang, Hai-Tsang Huang, Resources, Investigation; Diane E Lucente, Resources, Investigation, Writing—review and editing; Bradford C Dickerson, Conceptualization, Resources, Investigation, Writing—review and editing; Timothy J Mitchison, Conceptualization, Writing-review and editing; Eric S Fischer, Conceptualization, Resources, Supervision, Methodology, Writing-review and editing; Nathanael S Gray, Stephen J Haggarty, Conceptualization, Resources, Supervision, Funding acquisition, Methodology, Project administration, Writingreview and editing

Author ORCIDs

M Catarina Silva (iD http://orcid.org/0000-0001-5421-6673

Fleur M Ferguson (Did http://orcid.org/0000-0003-4091-7617

Katherine A Donovan (iD http://orcid.org/0000-0002-8539-5106

Ghata Nandi (iD) http://orcid.org/0000-0001-7170-8709

Hai-Tsang Huang (D) http://orcid.org/0000-0002-4244-2304

Eric S Fischer (iD http://orcid.org/0000-0001-7337-6306

Nathanael S Gray (D) https://orcid.org/0000-0001-5354-7403

Stephen J Haggarty (iD http://orcid.org/0000-0002-7872-168X

Decision letter and Author response

Decision letter https://doi.org/10.7554/eLife.45457.036

Author response https://doi.org/10.7554/eLife.45457.037

\section{Additional files}

Supplementary files

- Supplementary file 1. 1H NMR Spectra of QC-01-175.

DOI: https://doi.org/10.7554/eLife.45457.028

- Supplementary file 2. 1H NMR Spectra of QC-03-075.

DOI: https://doi.org/10.7554/eLife.45457.029

- Supplementary file 3. UPLC chromatogram and mass spectra of QC-01-175.

DOI: https://doi.org/10.7554/eLife.45457.030

- Supplementary file 4. UPLC chromatogram and mass spectra of QC-03-075.

DOI: https://doi.org/10.7554/eLife.45457.031

- Transparent reporting form

DOI: https://doi.org/10.7554/eLife.45457.032

Data availability

Mass spectrometry global proteomics data is available via the PRIDE archive, under the project accession number PXD012515. Source data files have been provided for Figures 2, 5 and 7.

The following dataset was generated:

\begin{tabular}{|c|c|c|c|c|}
\hline Author(s) & Year & Dataset title & Dataset URL & $\begin{array}{l}\text { Database and } \\
\text { Identifier }\end{array}$ \\
\hline Eric S Fischer & 2019 & $\begin{array}{l}\text { Targeted Degradation of Aberrant } \\
\text { Tau in Frontotemporal Dementia } \\
\text { Patient-Derived Neuronal Cell }\end{array}$ & $\begin{array}{l}\text { https://www.ebi.ac.uk/ } \\
\text { pride/archive/projects/ } \\
\text { PXD012515 }\end{array}$ & PRIDE，PXD012515 \\
\hline
\end{tabular}




\section{References}

Almeida S, Zhang Z, Coppola G, Mao W, Futai K, Karydas A, Geschwind MD, Tartaglia MC, Gao F, Gianni D, Sena-Esteves M, Geschwind DH, Miller BL, Farese RV, Gao FB. 2012. Induced pluripotent stem cell models of progranulin-deficient frontotemporal dementia uncover specific reversible neuronal defects. Cell Reports 2 : 789-798. DOI: https://doi.org/10.1016/j.celrep.2012.09.007, PMID: 23063362

Boland B, Kumar A, Lee S, Platt FM, Wegiel J, Yu WH, Nixon RA. 2008. Autophagy induction and autophagosome clearance in neurons: relationship to autophagic pathology in Alzheimer's disease. Journal of Neuroscience 28:6926-6937. DOI: https://doi.org/10.1523/JNEUROSCI.0800-08.2008, PMID: 18596167

Brunden KR, Ballatore C, Crowe A, Smith AB, Lee VM, Trojanowski JQ. 2010. Tau-directed drug discovery for alzheimer's disease and related tauopathies: a focus on tau assembly inhibitors. Experimental Neurology 223: 304-310. DOI: https://doi.org/10.1016/j.expneurol.2009.08.031, PMID: 19744482

Bulic B, Pickhardt M, Schmidt B, Mandelkow EM, Waldmann H, Mandelkow E. 2009. Development of tau aggregation inhibitors for alzheimer's disease. Angewandte Chemie International Edition 48:1740-1752. DOI: https://doi.org/10.1002/anie.200802621, PMID: 19189357

Chamberlain PP, Lopez-Girona A, Miller K, Carmel G, Pagarigan B, Chie-Leon B, Rychak E, Corral LG, Ren YJ, Wang M, Riley M, Delker SL, Ito T, Ando H, Mori T, Hirano Y, Handa H, Hakoshima T, Daniel TO, Cathers BE. 2014. Structure of the human Cereblon-DDB1-lenalidomide complex reveals basis for responsiveness to thalidomide analogs. Nature Structural \& Molecular Biology 21:803-809. DOI: https://doi.org/10.1038/nsmb. 2874, PMID: 25108355

Cheng C, Fass DM, Folz-Donahue K, MacDonald ME, Haggarty SJ. 2017. Highly expandable human iPS CellDerived neural progenitor cells (NPC) and neurons for central nervous system disease modeling and HighThroughput screening. Current Protocols in Human Genetics 92:8-21. DOI: https://doi.org/10.1002/cphg.33, PMID: 28075486

Chesselet MF, Carmichael ST. 2012. Animal models of neurological disorders. Neurotherapeutics 9:241-244. DOI: https://doi.org/10.1007/s13311-012-0118-9, PMID: 22460561

Chien DT, Bahri S, Szardenings AK, Walsh JC, Mu F, Su MY, Shankle WR, Elizarov A, Kolb HC. 2013. Early clinical PET imaging results with the novel PHF-tau radioligand [F-18]-T807. Journal of Alzheimer's Disease 34:457468. DOl: https://doi.org/10.3233/JAD-122059, PMID: 23234879

Collins I, Wang H, Caldwell JJ, Chopra R. 2017. Chemical approaches to targeted protein degradation through modulation of the ubiquitin-proteasome pathway. Biochemical Journal 474:1127-1147. DOI: https://doi.org/ 10.1042/BCJ20160762, PMID: 28298557

Congdon EE, Sigurdsson EM. 2018. Tau-targeting therapies for alzheimer disease. Nature Reviews Neurology 14:399-415. DOI: https://doi.org/10.1038/s41582-018-0013-z, PMID: 29895964

Coppola G, Chinnathambi S, Lee JJ, Dombroski BA, Baker MC, Soto-Ortolaza Al, Lee SE, Klein E, Huang AY, Sears R, Lane JR, Karydas AM, Kenet RO, Biernat J, Wang LS, Cotman CW, Decarli CS, Levey Al, Ringman JM, Mendez MF, et al. 2012. Evidence for a role of the rare p.A152T variant in MAPT in increasing the risk for FTDspectrum and Alzheimer's diseases. Human Molecular Genetics 21:3500-3512. DOI: https://doi.org/10.1093/ hmg/dds161, PMID: 22556362

Cowan CM, Mudher A. 2013. Are tau aggregates toxic or protective in tauopathies? Frontiers in Neurology 4: 114. DOI: https://doi.org/10.3389/fneur.2013.00114, PMID: 23964266

Cromm PM, Samarasinghe KTG, Hines J, Crews CM. 2018. Addressing Kinase-Independent functions of fak via PROTAC-Mediated degradation. Journal of the American Chemical Society 140:17019-17026. DOI: https:// doi.org/10.1021/jacs.8b08008

Cruts M, Van Broeckhoven C. 2015. Genetics of frontotemporal dementia and related disorders. In: Dickerson B. radfordC (Ed). Hodges' Frontotemporal Dementia. 2nd Edition. Cambridge University Press.

David DC, Layfield R, Serpell L, Narain Y, Goedert M, Spillantini MG. 2002. Proteasomal degradation of tau protein. Journal of Neurochemistry 83:176-185. DOI: https://doi.org/10.1046/j.1471-4159.2002.01137.x, PMID: 12358741

de Calignon A, Fox LM, Pitstick R, Carlson GA, Bacskai BJ, Spires-Jones TL, Hyman BT. 2010. Caspase activation precedes and leads to tangles. Nature 464:1201-1204. DOl: https://doi.org/10.1038/nature08890, PMID: 20357768

Deger JM, Gerson JE, Kayed R. 2015. The interrelationship of proteasome impairment and oligomeric intermediates in neurodegeneration. Aging Cell 14:715-724. DOl: https://doi.org/10.1111/acel.12359, PMID: 26053162

Del Prete D, Rice RC, Rajadhyaksha AM, D'Adamio L. 2016. Amyloid precursor protein (APP) May act as a substrate and a recognition unit for CRL4CRBN and Stub1 E3 ligases facilitating ubiquitination of proteins involved in presynaptic functions and neurodegeneration. Journal of Biological Chemistry 291:17209-17227. DOI: https://doi.org/10.1074/jbc.M116.733626, PMID: 27325702

DeVos SL, Miller RL, Schoch KM, Holmes BB, Kebodeaux CS, Wegener AJ, Chen G, Shen T, Tran H, Nichols B, Zanardi TA, Kordasiewicz HB, Swayze EE, Bennett CF, Diamond MI, Miller TM. 2017. Tau reduction prevents neuronal loss and reverses pathological tau deposition and seeding in mice with tauopathy. Science Translational Medicine 9:eaag0481. DOI: https://doi.org/10.1126/scitrans/med.aag0481, PMID: 28123067 
Dobrovolsky D, Wang ES, Morrow S, Leahy C, Faust T, Nowak RP, Donovan KA, Yang G, Li Z, Fischer ES, Treon SP, Weinstock DM, Gray NS. 2019. Bruton tyrosine kinase degradation as a therapeutic strategy for cancer. Blood 133:952-961. DOI: https://doi.org/10.1182/blood-2018-07-862953, PMID: 30545835

Dolan PJ, Johnson GV. 2010. The role of tau kinases in Alzheimer's disease. Current Opinion in Drug Discovery \& Development 13:595-603. PMID: 20812151

Dolmetsch R, Geschwind DH. 2011. The human brain in a dish: the promise of iPSC-derived neurons. Cell 145: 831-834. DOl: https://doi.org/10.1016/j.cell.2011.05.034, PMID: 21663789

Donovan KA, An J, Nowak RP, Yuan JC, Fink EC, Berry BC, Ebert BL, Fischer ES. 2018. Thalidomide promotes degradation of SALL4, a transcription factor implicated in Duane radial ray syndrome. eLife 7:e38340. DOI: https://doi.org/10.7554/eLife.38430, PMID: 30067223

Fischer ES, Böhm K, Lydeard JR, Yang H, Stadler MB, Cavadini S, Nagel J, Serluca F, Acker V, Lingaraju GM, Tichkule RB, Schebesta M, Forrester WC, Schirle M, Hassiepen U, Ottl J, Hild M, Beckwith RE, Harper JW, Jenkins JL, et al. 2014. Structure of the DDB1-CRBN E3 ubiquitin ligase in complex with thalidomide. Nature 512:49-53. DOI: https://doi.org/10.1038/nature13527, PMID: 25043012

Fong H, Wang C, Knoferle J, Walker D, Balestra ME, Tong LM, Leung L, Ring KL, Seeley WW, Karydas A, Kshirsagar MA, Boxer AL, Kosik KS, Miller BL, Huang Y. 2013. Genetic correction of tauopathy phenotypes in neurons derived from human induced pluripotent stem cells. Stem Cell Reports 1:226-234. DOI: https://doi. org/10.1016/j.stemcr.2013.08.001, PMID: 24319659

Galvin JE, Howard DH, Denny SS, Dickinson S, Tatton N. 2017. The social and economic burden of frontotemporal degeneration. Neurology 89:2049-2056. DOI: https://doi.org/10.1212/WNL. 0000000000004614, PMID: 28978658

Gechijian LN, Buckley DL, Lawlor MA, Reyes JM, Paulk J, Ott CJ, Winter GE, Erb MA, Scott TG, Xu M, Seo HS, Dhe-Paganon S, Kwiatkowski NP, Perry JA, Qi J, Gray NS, Bradner JE. 2018. Functional TRIM24 degrader via conjugation of ineffectual bromodomain and VHL ligands. Nature Chemical Biology 14:405-412. DOI: https:// doi.org/10.1038/s41589-018-0010-y, PMID: 29507391

Ghetti B, Oblak AL, Boeve BF, Johnson KA, Dickerson BC, Goedert M. 2015. Invited review: frontotemporal dementia caused by microtubule-associated protein tau gene (MAPT) mutations: a chameleon for neuropathology and neuroimaging. Neuropathology and Applied Neurobiology 41:24-46. DOI: https://doi. org/10.1111/nan.12213, PMID: 25556536

Gobbi LC, Knust H, Körner M, Honer M, Czech C, Belli S, Muri D, Edelmann MR, Hartung T, Erbsmehl I, GrallUlsemer S, Koblet A, Rueher M, Steiner S, Ravert HT, Mathews WB, Holt DP, Kuwabara H, Valentine H, Dannals $\mathrm{RF}$, et al. 2017. Identification of three novel radiotracers for imaging aggregated tau in Alzheimer's disease with positron emission tomography. Journal of Medicinal Chemistry 60:7350-7370. DOI: https://doi.org/10. 1021/acs.jmedchem.7b00632, PMID: 28654263

Goedert M. 2004. Tau protein and neurodegeneration. Seminars in Cell \& Developmental Biology 15:45-49. DOI: https://doi.org/10.1016/j.semcdb.2003.12.015, PMID: 15036206

Götz J, Xia D, Leinenga G, Chew YL, Nicholas H. 2013. What renders TAU toxic. Frontiers in Neurology 4:72. DOI: https://doi.org/10.3389/fneur.2013.00072, PMID: 23772223

Gu J, Congdon EE, Sigurdsson EM. 2013. Two novel tau antibodies targeting the 396/404 region are primarily taken up by neurons and reduce tau protein pathology. Journal of Biological Chemistry 288:33081-33095. DOI: https://doi.org/10.1074/jbc.M113.494922, PMID: 24089520

Gu S, Cui D, Chen X, Xiong X, Zhao Y. 2018. PROTACs: an emerging targeting technique for protein degradation in drug discovery. BioEssays 40:1700247. DOI: https://doi.org/10.1002/bies.201700247

Holt DP, Ravert HT, Dannals RF. 2016. Synthesis and quality control of [(18) F]T807 for tau PET imaging. Journal of Labelled Compounds \& Radiopharmaceuticals 59:411-415. DOI: https://doi.org/10.1002/jlcr.3425, PMID: 27427174

Huang HT, Dobrovolsky D, Paulk J, Yang G, Weisberg EL, Doctor ZM, Buckley DL, Cho JH, Ko E, Jang J, Shi K, Choi HG, Griffin JD, Li Y, Treon SP, Fischer ES, Bradner JE, Tan L, Gray NS. 2018. A chemoproteomic approach to query the degradable kinome using a Multi-kinase degrader. Cell Chemical Biology 25:88-99. DOI: https:// doi.org/10.1016/j.chembiol.2017.10.005, PMID: 29129717

Huang X, Dixit VM. 2016. Drugging the undruggables: exploring the ubiquitin system for drug development. Cell Research 26:484-498. DOI: https://doi.org/10.1038/cr.2016.31, PMID: 27002218

Inoue H, Nagata N, Kurokawa H, Yamanaka S. 2014. iPS cells: a game changer for future medicine. The EMBO Journal 33:409-417. DOI: https://doi.org/10.1002/embj.201387098, PMID: 24500035

Jiang B, Wang ES, Donovan KA, Liang Y, Fischer ES, Zhang T, Gray NS. 2019. Development of dual and selective degraders of Cyclin-Dependent kinases 4 and 6. Angewandte Chemie International Edition 13. DOI: https:// doi.org/10.1002/anie.201901336

Johnson KA, Schultz A, Betensky RA, Becker JA, Sepulcre J, Rentz D, Mormino E, Chhatwal J, Amariglio R, Papp K, Marshall G, Albers M, Mauro S, Pepin L, Alverio J, Judge K, Philiossaint M, Shoup T, Yokell D, Dickerson B, et al. 2016. Tau positron emission tomographic imaging in aging and early alzheimer disease. Annals of Neurology 79:110-119. DOI: https://doi.org/10.1002/ana.24546, PMID: 26505746

Johnson GV, Stoothoff WH. 2004. Tau phosphorylation in neuronal cell function and dysfunction. Journal of Cell Science 117:5721-5729. DOI: https://doi.org/10.1242/jcs.01558, PMID: 15537830

Jones DT, Knopman DS, Graff-Radford J, Syrjanen JA, Senjem ML, Schwarz CG, Dheel C, Wszolek Z, Rademakers R, Kantarci K, Petersen RC, Jack CR, Lowe VJ, Boeve BF. 2018. In vivo ${ }^{18} \mathrm{~F}-\mathrm{AV}$ - 1451 tau PET signal in MAPT mutation carriers varies by expected tau isoforms. Neurology 90:e947-e954. DOI: https://doi.org/10. 1212/WNL.0000000000005117, PMID: 29440563 
Keck S, Nitsch R, Grune T, Ullrich O. 2003. Proteasome inhibition by paired helical filament-tau in brains of patients with Alzheimer's disease. Journal of Neurochemistry 85:115-122. DOI: https://doi.org/10.1046/j.14714159.2003.01642.x, PMID: 12641733

Kopeikina KJ, Hyman BT, Spires-Jones TL. 2012. Soluble forms of tau are toxic in Alzheimer's disease. Translational Neuroscience 3:223-233. DOI: https://doi.org/10.2478/s13380-012-0032-y, PMID: 23029602

Kosik KS, Kowall NW, McKee A. 1989. Along the way to a neurofibrillary tangle: a look at the structure of tau. Annals of Medicine 21:109-112. DOI: https://doi.org/10.3109/07853898909149195, PMID: 2504256

Krönke J, Udeshi ND, Narla A, Grauman P, Hurst SN, McConkey M, Svinkina T, Heckl D, Comer E, Li X, Ciarlo C, Hartman E, Munshi N, Schenone M, Schreiber SL, Carr SA, Ebert BL. 2014. Lenalidomide causes selective degradation of IKZF1 and IKZF3 in multiple myeloma cells. Science 343:301-305. DOI: https://doi.org/10.1126/ science.1244851, PMID: 24292625

Krüger U, Wang Y, Kumar S, Mandelkow EM. 2012. Autophagic degradation of tau in primary neurons and its enhancement by trehalose. Neurobiology of Aging 33:2291-2305. DOI: https://doi.org/10.1016/j. neurobiolaging.2011.11.009, PMID: 22169203

Kumaraswamy S, Tobias R. 2015. Label-free kinetic analysis of an antibody-antigen interaction using biolayer interferometry. Methods in Molecular Biology 1278:165-182. DOI: https://doi.org/10.1007/978-1-4939-2425-7 10, PMID: 25859949

Lai AC, Crews CM. 2017. Induced protein degradation: an emerging drug discovery paradigm. Nature Reviews Drug Discovery 16:101-114. DOI: https://doi.org/10.1038/nrd.2016.211, PMID: 27885283

Lan H, Tang Z, Jin H, Sun Y. 2016. Neddylation inhibitor MLN4924 suppresses growth and migration of human gastric cancer cells. Scientific Reports 6:24218. DOI: https://doi.org/10.1038/srep24218, PMID: 27063292

Lemoine L, Leuzy A, Chiotis K, Rodriguez-Vieitez E, Nordberg A. 2018. Tau positron emission tomography imaging in tauopathies: the added hurdle of off-target binding. Alzheimer's \& Dementia: Diagnosis, Assessment \& Disease Monitoring 10:232-236. DOI: https://doi.org/10.1016/j.dadm.2018.01.007

Lowe VJ, Curran G, Fang P, Liesinger AM, Josephs KA, Parisi JE, Kantarci K, Boeve BF, Pandey MK, Bruinsma T, Knopman DS, Jones DT, Petrucelli L, Cook CN, Graff-Radford NR, Dickson DW, Petersen RC, Jack CR, Murray ME. 2016. An autoradiographic evaluation of AV-1451 tau PET in dementia. Acta Neuropathologica Communications 4:58. DOI: https://doi.org/10.1186/s40478-016-0315-6, PMID: 27296779

Lu G, Middleton RE, Sun H, Naniong M, Ott CJ, Mitsiades CS, Wong KK, Bradner JE, Kaelin WG. 2014. The myeloma drug lenalidomide promotes the cereblon-dependent destruction of ikaros proteins. Science $\mathbf{3 4 3}$ : 305-309. DOl: https://doi.org/10.1126/science.1244917, PMID: 24292623

Marquié M, Normandin MD, Vanderburg CR, Costantino IM, Bien EA, Rycyna LG, Klunk WE, Mathis CA, Ikonomovic MD, Debnath ML, Vasdev N, Dickerson BC, Gomperts SN, Growdon JH, Johnson KA, Frosch MP, Hyman BT, Gómez-Isla T. 2015. Validating novel tau positron emission tomography tracer [F-18]-AV-1451 (T807) on postmortem brain tissue. Annals of Neurology 78:787-800. DOI: https://doi.org/10.1002/ana.24517, PMID: 26344059

McAlister GC, Nusinow DP, Jedrychowski MP, Wühr M, Huttlin EL, Erickson BK, Rad R, Haas W, Gygi SP. 2014. MultiNotch MS3 enables accurate, sensitive, and multiplexed detection of differential expression across cancer cell line proteomes. Analytical Chemistry 86:7150-7158. DOI: https://doi.org/10.1021/ac502040v, PMID: 24 927332

Medina M. 2018. An overview on the clinical development of Tau-Based therapeutics. International Journal of Molecular Sciences 19:1160. DOI: https://doi.org/10.3390/ijms19041160

Metzger MB, Pruneda JN, Klevit RE, Weissman AM. 2014. RING-type E3 ligases: master manipulators of E2 ubiquitin-conjugating enzymes and ubiquitination. Biochimica Et Biophysica Acta (BBA) - Molecular Cell Research 1843:47-60. DOl: https://doi.org/10.1016/j.bbamcr.2013.05.026

Mignon L, Kordasiewicz H, Lane R, Smith A, Miller T, Narayanan P, Swayze E, Norris D, Fitzsimmons B, Bennett F. 2018. Design of the First-in-Human study of IONIS-MAPTRx, a Tau-lowering antisense oligonucleotide, in patients with alzheimer disease (S2.006). Neurology 90.

Min SW, Chen X, Tracy TE, Li Y, Zhou Y, Wang C, Shirakawa K, Minami SS, Defensor E, Mok SA, Sohn PD, Schilling B, Cong X, Ellerby L, Gibson BW, Johnson J, Krogan N, Shamloo M, Gestwicki J, Masliah E, et al. 2015. Critical role of acetylation in tau-mediated neurodegeneration and cognitive deficits. Nature Medicine 21:1154-1162. DOI: https://doi.org/10.1038/nm.3951, PMID: 26390242

Mirra SS, Murrell JR, Gearing M, Spillantini MG, Goedert M, Crowther RA, Levey Al, Jones R, Green J, Shoffner JM, Wainer BH, Schmidt ML, Trojanowski JQ, Ghetti B. 1999. Tau pathology in a family with dementia and a P301L mutation in tau. Journal of Neuropathology and Experimental Neurology 58:335-345. DOI: https://doi. org/10.1097/00005072-199904000-00004, PMID: 10218629

Morris M, Maeda S, Vossel K, Mucke L. 2011. The many faces of tau. Neuron 70:410-426. DOI: https://doi.org/ 10.1016/j.neuron.2011.04.009, PMID: 21555069

Murugan NA, Nordberg A, Ågren H. 2018. Different positron emission tomography tau tracers bind to multiple binding sites on the tau fibril: insight from computational modeling. ACS Chemical Neuroscience 9:1757-1767. DOI: https://doi.org/10.1021/acschemneuro.8b00093, PMID: 29630333

Myeku N, Duff KE. 2018. Targeting the $26 \mathrm{~S}$ proteasome to protect against proteotoxic diseases. Trends in Molecular Medicine 24:18-29. DOI: https://doi.org/10.1016/j.molmed.2017.11.006, PMID: 29233753

Neumann M, Kovacs GG, Mackenzie IRA. 2015. Neuropathology of frontotemporal dementia and related disorders. In: Dickerson B, Radford C (Eds). Hodges' Frontotemporal Dementia. Cambridge University Press. p. 165-184. 
Novak P, Schmidt R, Kontsekova E, Zilka N, Kovacech B, Skrabana R, Vince-Kazmerova Z, Katina S, Fialova L, Prcina M, Parrak V, Dal-Bianco P, Brunner M, Staffen W, Rainer M, Ondrus M, Ropele S, Smisek M, Sivak R, Winblad B, et al. 2017. Safety and immunogenicity of the tau vaccine AADvac1 in patients with Alzheimer's disease: a randomised, double-blind, placebo-controlled, phase 1 trial. The Lancet Neurology 16:123-134. DOI: https://doi.org/10.1016/S1474-4422(16)30331-3, PMID: 27955995

Nowak RP, DeAngelo SL, Buckley D, He Z, Donovan KA, An J, Safaee N, Jedrychowski MP, Ponthier CM, Ishoey M, Zhang T, Mancias JD, Gray NS, Bradner JE, Fischer ES. 2018. Plasticity in binding confers selectivity in ligand-induced protein degradation. Nature Chemical Biology 14:706-714. DOI: https://doi.org/10.1038/ s41589-018-0055-y, PMID: 29892083

Okuda M, Hijikuro I, Fujita Y, Wu X, Nakayama S, Sakata Y, Noguchi Y, Ogo M, Akasofu S, Ito Y, Soeda Y, Tsuchiya N, Tanaka N, Takahashi T, Sugimoto H. 2015. PE859, a novel tau aggregation inhibitor, reduces aggregated tau and prevents onset and progression of neural dysfunction in vivo. PLoS One 10:e0117511. DOI: https://doi.org/10.1371/journal.pone.0117511, PMID: 25659102

Okuda M, Fujita Y, Hijikuro I, Wada M, Uemura T, Kobayashi Y, Waku T, Tanaka N, Nishimoto T, Izumi Y, Kume T, Akaike A, Takahashi T, Sugimoto H. 2017. PE859, A Novel Curcumin Derivative, Inhibits Amyloid- $\beta$ and Tau Aggregation, and Ameliorates Cognitive Dysfunction in Senescence-Accelerated Mouse Prone 8. Journal of Alzheimer's Disease 59:313-328. DOI: https://doi.org/10.3233/JAD-161017, PMID: 28598836

Olney NT, Spina S, Miller BL. 2017. Frontotemporal Dementia. Neurologic Clinics 35:339-374. DOI: https://doi. org/10.1016/j.ncl.2017.01.008, PMID: 28410663

Panza F, Solfrizzi V, Seripa D, Imbimbo BP, Lozupone M, Santamato A, Zecca C, Barulli MR, Bellomo A, Pilotto A, Daniele A, Greco A, Logroscino G. 2016. Tau-Centric targets and drugs in clinical development for the treatment of alzheimer's disease. BioMed Research International 2016:3245935. DOI: https://doi.org/10.1155/ 2016/3245935, PMID: 27429978

Pedersen JT, Sigurdsson EM. 2015. Tau immunotherapy for Alzheimer's disease. Trends in Molecular Medicine 21:394-402. DOI: https://doi.org/10.1016/j.molmed.2015.03.003, PMID: 25846560

Petersen RL. 2017. Strategies using bio-layer interferometry biosensor technology for vaccine research and development. Biosensors 7:E49. DOI: https://doi.org/10.3390/bios7040049, PMID: 29088096

Ritchie ME, Phipson B, Wu D, Hu Y, Law CW, Shi W, Smyth GK. 2015. limma powers differential expression analyses for RNA-sequencing and microarray studies. Nucleic Acids Research 43:e47. DOI: https://doi.org/10. 1093/nar/gkv007, PMID: 25605792

Rubinsztein DC, Bento CF, Deretic V. 2015. Therapeutic targeting of autophagy in neurodegenerative and infectious diseases. The Journal of Experimental Medicine 212:979-990. DOI: https://doi.org/10.1084/jem. 20150956, PMID: 26101267

Saez I, Vilchez D. 2014. The mechanistic links between proteasome activity, aging and age-related diseases. Current genomics 15:38-51. DOI: https://doi.org/10.2174/138920291501140306113344, PMID: 24653662

Saint-Aubert L, Lemoine L, Chiotis K, Leuzy A, Rodriguez-Vieitez E, Nordberg A. 2017. Tau PET imaging: present and future directions. Molecular Neurodegeneration 12:19. DOI: https://doi.org/10.1186/s13024-017-0162-3, PMID: 28219440

Santacruz K, Lewis J, Spires T, Paulson J, Kotilinek L, Ingelsson M, Guimaraes A, DeTure M, Ramsden M, McGowan E, Forster C, Yue M, Orne J, Janus C, Mariash A, Kuskowski M, Hyman B, Hutton M, Ashe KH. 2005. Tau suppression in a neurodegenerative mouse model improves memory function. Science 309:476-481. DOI: https://doi.org/10.1126/science.1113694, PMID: 16020737

Schöll M, Lockhart SN, Schonhaut DR, O’Neil JP, Janabi M, Ossenkoppele R, Baker SL, Vogel JW, Faria J, Schwimmer HD, Rabinovici GD, Jagust WJ. 2016. PET imaging of tau deposition in the aging human Brain. Neuron 89:971-982. DOI: https://doi.org/10.1016/j.neuron.2016.01.028, PMID: 26938442

Schonhaut DR, McMillan CT, Spina S, Dickerson BC, Siderowf A, Devous MD, Tsai R, Winer J, Russell DS, Litvan I, Roberson ED, Seeley WW, Grinberg LT, Kramer JH, Miller BL, Pressman P, Nasrallah I, Baker SL, Gomperts SN Johnson KA, et al. 2017. ${ }^{18} \mathrm{~F}$-flortaucipir tau positron emission tomography distinguishes established progressive supranuclear palsy from controls and Parkinson disease: A multicenter study. Annals of Neurology 82:622-634. DOl: https://doi.org/10.1002/ana.25060, PMID: 28980714

Seo J, Kritskiy O, Watson LA, Barker SJ, Dey D, Raja WK, Lin YT, Ko T, Cho S, Penney J, Silva MC, Sheridan SD, Lucente D, Gusella JF, Dickerson BC, Haggarty SJ, Tsai LH. 2017. Inhibition of p25/Cdk5 attenuates tauopathy in mouse and iPSC models of frontotemporal dementia. The Journal of Neuroscience 37:9917-9924. DOI: https://doi.org/10.1523/JNEUROSCI.0621-17.2017, PMID: 28912154

Shah NB, Duncan TM. 2014. Bio-layer interferometry for measuring kinetics of protein-protein interactions and allosteric ligand effects. Journal of Visualized Experiments 84:e51383. DOI: https://doi.org/10.3791/51383

Sheridan SD, Theriault KM, Reis SA, Zhou F, Madison JM, Daheron L, Loring JF, Haggarty SJ. 2011. Epigenetic characterization of the FMR1 gene and aberrant neurodevelopment in human induced pluripotent stem cell models of fragile X syndrome. PLoS One 6:e26203. DOI: https://doi.org/10.1371/journal.pone.0026203, PMID: 22022567

Sievers QL, Petzold G, Bunker RD, Renneville A, Słabicki M, Liddicoat BJ, Abdulrahman W, Mikkelsen T, Ebert $\mathrm{BL}$, Thomä NH. 2018. Defining the human $\mathrm{C} 2 \mathrm{H} 2$ zinc finger degrome targeted by thalidomide analogs through CRBN. Science 362:eaat0572. DOI: https://doi.org/10.1126/science.aat0572, PMID: 30385546

Silva MC, Cheng C, Mair W, Almeida S, Fong H, Biswas MHU, Zhang Z, Huang Y, Temple S, Coppola G, Geschwind DH, Karydas A, Miller BL, Kosik KS, Gao FB, Steen JA, Haggarty SJ. 2016. Human iPSC-derived neuronal model of Tau-A152T frontotemporal dementia reveals tau-mediated mechanisms of neuronal 
vulnerability. Stem Cell Reports 7:325-340. DOI: https://doi.org/10.1016/j.stemcr.2016.08.001, PMID: 275945 85

Silva MC, Cross A, Brandon NJ, Haggarty SJ. 2017. Human iPSC Models in Drug Discovery: Opportunities and Challenges. In: Rotella D. avidP, Ward S. imonE, Chackalamannil S. amuel (Eds). Comprehensive Medicinal Chemistry III. Oxford: Elsevier. p. 48-73.

Smith R, Puschmann A, Schöll M, Ohlsson T, van Swieten J, Honer M, Englund E, Hansson O. 2016. 18F-AV-1451 tau PET imaging correlates strongly with tau neuropathology in MAPT mutation carriers. Brain 139:2372-2379. DOI: https://doi.org/10.1093/brain/aww163, PMID: 27357347

Smith R, Wibom M, Pawlik D, Englund E, Hansson O. 2018. Correlation of In Vivo [18F]Flortaucipir With Postmortem Alzheimer Disease Tau Pathology. JAMA neurology. DOI: https://doi.org/10.1001/jamaneurol. 2018.3692, PMID: 30508025

Spina S, Schonhaut DR, Boeve BF, Seeley WW, Ossenkoppele R, O'Neil JP, Lazaris A, Rosen HJ, Boxer AL, Perry DC, Miller BL, Dickson DW, Parisi JE, Jagust WJ, Murray ME, Rabinovici GD. 2017. Frontotemporal dementia with the V337M MAPT mutation: Tau-PET and pathology correlations. Neurology 88:758-766. DOI: https://doi. org/10.1212/WNL.0000000000003636, PMID: 28130473

Spires TL, Orne JD, SantaCruz K, Pitstick R, Carlson GA, Ashe KH, Hyman BT. 2006. Region-specific dissociation of neuronal loss and neurofibrillary pathology in a mouse model of tauopathy. The American Journal of Pathology 168:1598-1607. DOI: https://doi.org/10.2353/ajpath.2006.050840, PMID: 16651626

Tian H, Davidowitz E, Lopez P, Emadi S, Moe J, Sierks M. 2013. Trimeric tau is toxic to human neuronal cells at low nanomolar concentrations. International Journal of Cell Biology 2013:1-9. DOI: https://doi.org/10.1155/ 2013/260787

Vermeiren C, Motte P, Viot D, Mairet-Coello G, Courade JP, Citron M, Mercier J, Hannestad J, Gillard M. 2018. The tau positron-emission tomography tracer AV-1451 binds with similar affinities to tau fibrils and monoamine oxidases. Movement Disorders 33:273-281. DOI: https://doi.org/10.1002/mds.27271, PMID: 29278274

Wan W, Cao L, Kalionis B, Xia S, Tai X. 2015. Applications of induced pluripotent stem cells in studying the neurodegenerative diseases. Stem Cells International 2015:1-11. DOI: https://doi.org/10.1155/2015/382530

Wang Y, Martinez-Vicente M, Krüger U, Kaushik S, Wong E, Mandelkow EM, Cuervo AM, Mandelkow E. 2009. Tau fragmentation, aggregation and clearance: the dual role of lysosomal processing. Human Molecular Genetics 18:4153-4170. DOI: https://doi.org/10.1093/hmg/ddp367, PMID: 19654187

Wang Y, Mandelkow E. 2012. Degradation of tau protein by autophagy and proteasomal pathways. Biochemical Society Transactions 40:644-652. DOI: https://doi.org/10.1042/BST20120071, PMID: 22817709

Xia CF, Arteaga J, Chen G, Gangadharmath U, Gomez LF, Kasi D, Lam C, Liang Q, Liu C, Mocharla VP, Mu F, Sinha A, Su H, Szardenings AK, Walsh JC, Wang E, Yu C, Zhang W, Zhao T, Kolb HC. 2013. [(18)F]T807, a novel tau positron emission tomography imaging agent for Alzheimer's disease. Alzheimer's \& Dementia 9:666-676. DOI: https://doi.org/10.1016/j.jalz.2012.11.008, PMID: 23411393

Xie T, Lim SM, Westover KD, Dodge ME, Ercan D, Ficarro SB, Udayakumar D, Gurbani D, Tae HS, Riddle SM, Sim T, Marto JA, Jänne PA, Crews CM, Gray NS. 2014. Pharmacological targeting of the pseudokinase Her3. Nature Chemical Biology 10:1006-1012. DOI: https://doi.org/10.1038/nchembio.1658, PMID: 25326665

Xu H, Rösler TW, Carlsson T, de Andrade A, Fiala O, Hollerhage M, Oertel WH, Goedert M, Aigner A, Höglinger GU. 2014. Tau silencing by siRNA in the P301S mouse model of tauopathy. Current Gene Therapy 14:343-351. PMID: 25687501

Yanamandra K, Kfoury N, Jiang H, Mahan TE, Ma S, Maloney SE, Wozniak DF, Diamond MI, Holtzman DM. 2013. Anti-tau antibodies that block tau aggregate seeding in vitro markedly decrease pathology and improve cognition in vivo. Neuron 80:402-414. DOI: https://doi.org/10.1016/j. neuron.2013.07.046, PMID: 24075978 